\title{
Earnings Warnings and CEO Welfare
}

\author{
Ping Wang \\ Pace University \\ pwang@pace.edu \\ Masako Darrough \\ Baruch College, CUNY \\ masako.darrough@baruch.cuny.edu
}

November, 2011 


\title{
Earnings Warnings and CEO Welfare
}

\begin{abstract}
Some CEOs decide to voluntarily issue warnings when they expect a negative earnings surprise. Prior research suggests that warnings have incremental information beyond actual earnings and warning firms tend to experience permanent, instead of transitory, earnings decreases. This paper investigates whether boards of directors consider the issuance of warnings when evaluating CEO performance. In particular, this study examines the effect of warnings on CEO compensation (annual bonus and option grants) and turnover. We find that warnings are significantly negatively associated with CEO bonus, but positively associated with option grants. This finding indicates that boards of directors adjust CEO compensation toward a more future-oriented structure after warnings are issued. We also find that after warnings are issued, the sensitivity of bonus to stock returns increases significantly, although the sensitivity of option grants to stock returns does not differ from that of non-warning firms. Furthermore, we provide evidence that both CEOs bonus and option grants incorporate peer firms' performance (i.e., stock returns and warnings) to filter out the external shocks that are common to the industry peers. Lastly, we show that as another potential direct benefit for CEOs, issuing warnings reduces CEO turnover. Overall, these findings suggest that the signal from warnings is used in determining CEO compensation and job retention.
\end{abstract}




\section{Introduction}

When faced with an impending negative earnings surprise, CEOs have to decide whether to voluntarily issue earnings warnings. Warnings are negative earnings guidance issued when (expected) actual earnings fall short of the existing market expectations, typically issued near or after the end of the fiscal quarter. ${ }^{1}$ Upon the issuance of warnings, the market adjusts its expectations often by dropping stock prices (Kasznik and Lev 1995; Tucker 2007). Analysts might also adjust their forecasts. Prior studies find that issuing earnings guidance reduces litigation cost (Skinner 1997), reduces information asymmetry among investors (Coller and Yohn 1997), increases the number of analysts following (Lang and Lundholm 1996a), and increases the chance of meeting or beating analysts' forecasts (Cotter, Tuna, and Wysocki 2006). ${ }^{2}$ Given that these firms tend to be performing poorly (at least below the market expectations), issuing warnings appears to be an integral part of timely disclosure of bad news. Yet, evidence in prior literature suggests that less than $25 \%$ of firms preempt negative earnings surprises (Skinner 1994; Kasznik and Lev 1995). ${ }^{3}$

When firms expect to fall short of market expectations, investors would want timely disclosure of bad news. Given the positions firms are in, issuing warnings appear to bring some benefits to issuing firms, while costs appear to be small since negative market reactions are likely to happen anyway either at the time of warnings or actual earnings announcements. If there is little cost, one would expect that most firms that face an earnings surprise would issue warnings so that the investors would not be caught off guard. Thus, it is surprising that relatively small number of companies issue warnings when they face negative earnings surprises. Clearly, the decision whether or not to issue warnings is not as

\footnotetext{
${ }^{1}$ The earnings guidance issued in the face of earnings surprise can come in the form of warnings or tip-offs. Tip-offs are defined as positive earnings guidance (i.e., guidance that exceeds the existing market expectations). Using a sample of 494 tip-off firms and 9,028 non-tip-off control firms from the same time period as used in testing warnings, we find little evidence (untabulated) that tip-offs affect CEO bonus and option grants. This finding supports the argument that voluntary disclosures of good news (e.g., tip-offs) are less credible than bad news (e.g., warnings) (Sansing 1992; Jennings 1987; Hutton, Miller, and Skinner 2003; Rogers and Stocken 2005).

${ }^{2}$ Houston, Lev, and Tucker (2010) and Chen, Matsumoto, and Rajgopal (2011) study the firms that stopped issuing earnings guidance and find similar results; forecast accuracy is reduced and forecast dispersion is increased after firms cease management earnings guidance. For a comprehensive review of benefits and costs of providing earnings guidance, see http://www.capmktsreg.org/pdfs/09-Sept-15_CCMR-Miller_Study_on_Earnings_Guidance.pdf.

${ }^{3}$ Less than $10 \%$ of firms preempt positive earnings surprises.
} 
straightforward as one might think. In this paper, we examine the consequences of warnings that might directly accrue to those CEOs who have to decide whether or not to issue warnings. Specifically, what are the consequences of providing warnings with respect to CEO compensation and turnover? We ask four questions: (1) Do warnings affect CEO compensation, i.e., bonus and option grants? (2) Does the sensitivity of bonus and option grants to performance change when warnings are issued? (3) Conditional on the decision to warn, what is the effect of peer firms' warnings on a firm's sensitivity of bonus and option grants to performance? (4) Do warnings affect CEO turnover?

Research that directly examines the relation between management earnings guidance and CEO compensation is limited. Focusing on options that have fixed award schedule, Aboody and Kasznik (2000) show that CEOs are more likely to issue negative earnings guidance prior to the option grant dates. By timing the negative earnings guidance, CEOs try to lower the strike price on the grant date and increase the value of their stock option compensation. Nagar, Nandar and Wysocki (2003) argue that CEOs with greater levels of equity holdings have incentives to issue earnings guidance in order to avoid equity mispricing which may adversely affect their wealth. However, neither of these papers looks at the bonus component of the CEO compensation nor new stock options that might be granted. Moreover, the evidence in their studies is ex ante. It shows that equity compensation affects the decision to issue earnings guidance, but the ex post effect of the negative earnings guidance on CEO compensation has yet to be examined. Research on the association between earnings guidance and CEO turnover is also limited with the exception of Lee, Matsunaga, and Park (2010). They find evidence that probability of CEO turnover decreases with management guidance accuracy, indicating that management guidance acts as a signal regarding the CEOs' ability to handle business uncertainty. This study tries to fill this void in the literature.

First, we study the effect of warnings on annual CEO bonus and stock options. Results from Kasznik and Lev (1995) and Tucker (2007) suggest that warnings are issued for permanent earnings disappointments and transitory ones are unwarned. Specifically, Kasznik and Lev (1995) find that 
analysts adjust forecast of next year's earnings more negatively for warning firms, and Tucker (2007) shows that warning firms' next year performance is significantly lower than non-warnings firms'. This evidence suggests that the very act of issuing warnings could provide incremental information about the future prospect of the firms over and above the actual earnings that are to be released shortly after the warnings. Thus, compensation committees might use the information in setting CEO compensation; voluntarily issued warnings provide information about CEO performance (or type) that is incremental to accounting and stock-based returns. On the other hand, it is possible that compensation committees do not pay attention to warnings since actual earnings are available when they determine the CEO compensation level. Any information in the warnings could be subsumed by the actual earnings, which are more reliable. It is also possible that in trying to encourage CEOs to be more forthcoming about impending bad news, compensation committees shield CEOs from bad news; they do not "shoot the messenger." In these cases, the bonus of CEOs may not be affected by warnings. Taken together, it is an empirical question whether and how warnings affect CEO bonus.

Stock-based compensation is another important component of compensation contract. The poor performance signaled by warnings may indicate that the interests of managers are not well aligned with those of shareholders. If warning firms' equity incentive levels are deemed suboptimal, we expect that compensation committees grant more option-based compensation to provide more incentives to CEOs. Core, Guay, and Larcker (2003), among others, argue that equity incentive levels could affect CEOs' action and firm performance. The opportunistic timing of negative earnings guidance (i.e., warnings) by CEOs to maximize the value of their option grants may be allowed by the board of directors as an implicit form of compensation (Aboody and Kasznik 2000). In addition, granting more options can make up CEOs' potential bonus cuts, if there is any, and encourage CEOs to voluntarily disclose negative earnings guidance. 
Our sample for testing warning effect consists of 1,218 warning firms and 5,729 non-warning control firms from 1996-2005. ${ }^{4}$ After controlling for self-selection of warnings, we find that warnings are significantly negatively associated with CEO bonus and positively associated with option grants. It thus indicates that compensation committees view earnings warnings as an important performance measure incremental to actual earnings announced shortly after the warnings and shift the compensation structure from cash-based compensation toward more equity-based compensation.

The second issue we examine is the effect of warnings on bonus-to-performance and option-toperformance sensitivity. Lambert and Larcker (1987) argue that stock returns should become more useful in evaluating CEO performance when they are more informative about firm performance. Suppose when warnings are issued, stock returns incorporate information about firm performance and future prospect in a more timely fashion than do accounting earnings. Then we would expect compensation sensitivity to stock returns should increase. Consistent with this argument, we find that sensitivity of CEO bonus to stock returns increases significantly when warnings are issued, but warning firms' sensitivity of option grants to stock returns does not differ from non-warning firms'.

Third, we investigate the effect of peer firms' warnings on a firm's pay-performance sensitivity. Based on the literature on relative performance evaluation (RPE) and information transfer, we expect that the signal from peer firms' warnings is utilized in determining CEO compensation to filter out the systematic shocks that are common to industry peers. We find evidence that bonus-to-stock-returns and option-to-stock-returns sensitivities for warning firms decrease as the number of warning peers increases. Warnings by peer firms indicate an industry-wide effect and therefore CEO compensation will be less responsive to warnings.

Lastly, we explore the potential benefits of issuing warnings for CEOs. To see if there is any direct benefit to CEOs from issuing warnings, we empirically investigate whether CEOs are more likely to be retained, ceteris paribus, when they issue warnings. If management forecast accuracy (about future

\footnotetext{
${ }^{4}$ Non-warning control firms are defined as firms that (1) expected a negative earnings surprise and (2) decided not to warn. For details, refer to sample selection and descriptive statistics.
} 
prospects) is an indicator of ability (Trueman 1986 and Lee, Matsunaga, an Park 2010), we predict that warnings reduce CEO turnover by increasing perceived management ability. On the other hand, warning about impending earnings might not reflect managerial ability. In our empirical analysis, we find that CEO turnover is attenuated after issuing warnings. To assess the economic significance of this potential benefit, we calculate the marginal benefit of issuing warnings and find that, ceteris paribus, the turnover rate of warning firms is 5.9 percentage point lower than non-warning firms. Therefore, the effect of reduced turnover sensitivity is economically significant. Thus, we provide direct evidence of a benefit from issuing warnings for CEOs.

This paper contributes to the accounting literature in several ways. First, it adds to the literature on the determinants of CEO compensation by demonstrating that compensation committees also view the information conveyed in warnings as an important performance measure. Furthermore, we show that bonus-to-stock-returns sensitivity increases when warnings are issued, suggesting that in the presence of warnings, stock returns become more relevant in evaluating CEOs' performance.

Second, this paper extends the RPE literature by documenting an effect of peer firms' management guidance on a firm's pay-performance sensitivity. This finding sheds light on the long-term debate concerning RPE. Information transfer literature has mainly looked at how investors take account of information transferred among peer firms and among firms that in a supply chain (i.e., suppliers and buyers), but the internal usefulness of the information transferred has received less attention. This paper fills this gap by documenting that the information transferred is also used in the compensation contract.

Lastly, this study provides evidence on direct benefits of issuing warnings for CEOs. The result shows that CEO turnover is lower for warning firms than for non-warning firms. This evidence suggests that CEOs are willing to issue negative earnings guidance to help keep their jobs.

The remainder of the paper is organized as follows. Section 2 develops hypotheses. Sample selection and descriptive statistics are discussed in section 3. Research designs and empirical results are 
presented in section 4. Section 5 details the rob9ustness checks and further analysis and section 6 concludes the paper.

\section{Hypothesis Development}

\subsection{CEO Compensation and Pay-Performance Sensitivity}

The standard agency model (Holmstrom 1979) shows that agent's compensation is a function of the firm's performance, and optimal contracts should be based on the variables that are useful in assessing the agent's action and type, including the variables that may not be under direct control of the agent (e.g., macroeconomic factors and performance of competitors). Evidence from companies' proxy statement supports the prescription of the agency model. For example, J \& J Snack’s 2000 proxy statement states:

"...The Committee also considers matters which are likely to have a long term impact on the Company but may not be reflected on the annual financial statements."

Do compensation committees incorporate warnings as one of the "matters"? When compensation committees award bonus and option compensation to CEOs, they have at their disposal data on realized earnings; they would not have to rely on managerial forecasts to learn what earnings are. Therefore, the relevant question is what incremental information warnings provide to compensation committees that are not included in actual earnings and other financial results. If warnings are to provide any information that is relevant for compensation determination, they must contain incremental information about CEOs' effort or ability.

Kasznik and Lev (1995) document lower abnormal returns for firms that issue warnings about impending earnings disappointments than returns for non-warning firms during a combined window of 5 days around warnings and 5 days around earnings announcements. ${ }^{5}$ More importantly, they argue that warnings are issued for permanent earnings disappointments while transitory earnings disappointments

\footnotetext{
5 After controlling for self-selection and expanding the test window to three months, Tucker (2007) finds that warning firms still experience a lower abnormal return than non-warning firms during the three-month window starting from the beginning of the third fiscal month of the event quarter to one month after the earnings announcement. Although she does not find evidence of lower abnormal returns if the event window is further extended to two months after the end of the earnings announcement month, this finding may result from the contamination by other events.
} 
are not warned by showing that analysts adjust forecast of next year's earnings more negatively for warning firms. As accounting earnings reflect the past performance, the analysts' adjustment is more likely to reflect the incremental information revealed by warnings. This is also supported by the anecdotal evidence that warnings raise analysts' concern about the firms' long-term vitality. ${ }^{6}$ Therefore, compensation committees are likely to consider the implication of warnings when setting CEO compensation because warnings signal the persistence of earnings disappointments not reflected in actual earnings.

The two important component of CEO compensation are bonus and stock options. Thus, it is possible that compensation committees increase or decrease their CEO bonus and/or grant more or less stock options based on whether or not their CEOs issued warnings. The effect of warnings on CEO bonus depends on how the warning signals are interpreted. Bonuses could be reduced if CEOs (long-term) performance is viewed as poor. CEO bonus may not be affected if warning signals are viewed as devoid of any information incremental to the actual earnings. On the other hand, CEOs who voluntarily issue warnings may be viewed as more capable and forthright. In such a case, CEOs may not be penalized even though news is bad. ${ }^{7}$ Taken together, it is an empirical question as to whether and in what direction warnings affect CEO bonus. Therefore, our first hypothesis is stated in null form:

Hypothesis 1: Ceteris paribus, CEO bonus is not associated with whether an earnings warning is issued.

Next, we examine whether the sensitivity of CEO bonus to performance is affected by warnings. Lambert and Larcker (1987) suggest that market measures of performance, such as stock returns, become more useful for evaluating an agent's performance when the consequences of the agent's current actions tend to be realized in the future and are not fully reflected in current-period accounting numbers. Choi, et

\footnotetext{
${ }^{6}$ For example, Reuters News reports on October 25, 2002 "Deutsche Bank analysts Mark Cusak and Peter Reilly on Friday slashed their share price target for industrial engineer ABB to 0.1 Swiss francs from three francs following an earnings warning and nine-month loss.... 'ABB may be in loss for both this and next year,' they wrote in a note'. Another example is The Globe and Mail, which reports on March 23, 2011 "An earnings warning from Canadian Pacific Railway Ltd. has triggered an avalanche of cautionary notes from analysts, who see a series of challenges ahead for the fright carrier."

${ }^{7}$ As suggested by Murphy (1999), compensation committees have some discretion over the determination of a portion of bonuses even though a company has a bonus plan.
} 
al. (2010) show that current-period returns are more positively associated with future earnings for guidance firms than for non-guidance firms, indicating that warnings provide incremental information that allows stock returns to better reflect future earnings. Thus, extending Lambert and Larcker's (1987) argument, we argue that CEO pay should be more closely tied to stock returns during the years warnings are issued. Thus, we expect that CEO bonus is more sensitive to stock returns when warnings are issued than when warnings are not issued.

Hypothesis 2: Ceteris paribus, the bonus sensitivity to stock returns is higher for warning firms than for non-warning firms.

Contrary to cash-based compensation, stock-based compensation is designed to provide direct incentives to increase firm values and share prices by aligning managers' interests with those of shareholders' (Jensen and Meckling 1976; Antle and Smith 1986; Core, Guay, and Verrecchia 2003). Consistent with this argument, Core and Larcker (2002) find that for a sample of firms that adopt "target ownership plans" (plans to require minimum of amount of stock), their performance improved significantly after CEOs increased their stock ownership as these firms had significantly lower level of equity holdings before adopting the plan. If warnings signal that the difficulty these firms are experiencing might persist into the future, then they might in turn suggest that the actions and the choices of CEOs have made so far are not well aligned with the welfare of shareholders. In such a case, compensation committees might shift the compensation structure to be more incentives-oriented by granting more stock options during the years warnings are issued. ${ }^{8}$ The preceding discussion leads to the following hypothesis:

Hypothesis 3: Ceteris paribus, warning firms experience an increase in their CEOs' option grants than non-warning firms .

\footnotetext{
${ }^{8}$ Bryan, Hwang, and Lilien (2000) document that restricted stock, due to its linear payoff function, is relatively inefficient in inducing risk-averse CEOs to accept risky but value-increasing investment projects. Additionally, restricted stock is not commonly used in compensation contract (Carter, Lynch, and Tuna 2007). Therefore, in this paper, we follow Cheng and Farber (2008) and focus on option compensation. In untabulated results, we also include restricted stock, and the conclusions are unchanged.
} 
As argued in Hypothesis 2, when warnings are issued, stock-returns reflect more information, which accounting-based earnings do not impound, and returns of warnings firms better reflect future earnings than do those of non-warning firms. Therefore, we expect that stock-based compensation will be more closely tied to stock-returns when warnings are issued. We state the following hypothesis in an alternative form,

Hypothesis 4: Ceteris paribus, the sensitivity of option grants to stock returns is higher for warning firms than for non-warning firms.

\subsection{Effect of Peer Firms' Warnings on a Firm's Pay-Performance Sensitivity}

Research on relative performance evaluation (RPE) focuses on how peers' reported accounting performance and stock returns affect CEO compensation (Gibbons and Murphy 1990; Jensen and Murphy 1990; Janakiraman, Lambert, and Larcker 1992; Aggarwal and Samwick 1999; Garvey and Milbourn 2003; Albuquerque 2009). ${ }^{9}$ Another stream of related literature studies the phenomenon of intra-industry information transfer, which is the effect of information disclosed by one industry member on the stock prices of other members (e.g., Lang and Stulz 1992; Lang and Lundholm 1996b). However, the literature only looks at external users' reactions to the information transferred such as investors' reactions but not internal users' reactions such as boards of directors'. Our study goes beyond peer firms' reported earnings on the stock returns of the firm in question and investigates whether peer firms' warnings affect the firm's CEO bonus (in the form of bonus-to-performance sensitivity) and stock options (in the form of optionsto-performance sensitivity). If the incremental information that is relevant to CEO compensation is about the longer-term outlook of the firm, then the information on the performance of their peer firms might be valuable in setting CEO incentive schemes (Holmstrom, 1979).

Firms grant a bonus to their CEO after the fiscal year ends and after the financials are released. Based on hypotheses 1 and 2, if warnings have incremental information beyond reported earnings and other financial numbers, the compensation committee of a firm may also consider the information content

\footnotetext{
${ }^{9}$ Evidence that peers' accounting-based earnings and stock returns are used in compensation contracts will be referred to as "conventional" RPE evidence hereafter.
} 
of its peer firms' warnings. Prior studies on information transfers from management forecasts (Baginski 1987; Han, Wild and Ramesh 1989) show that good (bad) news forecasts from a forecasting firm lead to a positive (negative) stock market reaction to non-forecasting firms in the same industry. These findings indicate that investors use information of peer firms' management forecasts to assess a firm's value. In addition, Lang and Lundholm (1996b) show a negative (positive) relation between a firm's return during the industry earnings announcement (pre-earnings-announcement) window and its peer firms' earnings surprises. Based on these results, they draw the inference that information regarding the industry-wide component of future value arrives in the pre-announcement period. As such, as an increasing number of peer firms issue warnings, it becomes clearer that the whole industry is performing poorly. In other words, by issuing earnings warnings along with its peers, the firm's CEOs may be able to attribute the poor performance of his firm to the industry or the market, and as a result, his bonus will be less sensitive to his firm's performance than otherwise.

If warning firms are accompanied with warning peers, then the presence of warning peers provides the CEOs with a reason to justify his substandard performance. In contrast, when warning CEOs do not have warning peers, they stand out, and it is more difficult for them to blame external factors for their poor performance. This is consistent with the findings in Tse and Tucker (2010) that managers tend to time their warnings soon after their peers' warnings in order to reduce their responsibility for earnings shortfalls. The third hypothesis is stated as follows:

Hypothesis 5: Ceteris paribus, conditional on the decision to warn, bonus-to-stock-returns sensitivity for warning firms decreases as the number of warning peers increases.

A similar argument suggests that when there are a large number of warning peers, boards of directors may not grant as many stock options as they would otherwise because the poor performance is no longer indicative of CEOs' suboptimal incentive rather is pertaining to some common external factors. Option grants then become less sensitive to stock-based returns for warning firms with more warning peers than for warning firms with fewer warning peers. The hypothesis is stated as follows: 
Hypothesis 6: Ceteris paribus, conditional on the decision to warn, the sensitivity of option grants to stock returns for warning firms decreases as the number of warning peers increases.

\subsection{Rational for Choosing to Warn: Job Retention Hypothesis}

Prior studies have documented some benefits of disclosing bad news for firms such as deterring entry (Darrough and Stoughton 1990) and reduced litigation cost (Skinner 1997). Nevertheless, Darrough (1995) points out that most disclosure studies have not explicitly modeled incentives of managers themselves. While some papers model managers' objective as a function of stock price, assuming managers hold companies' stocks, their compensation is not directly modeled (Trueman 1997; Dutta and Trueman 2002). As a first step toward empirically exploring direct benefits of issuing warnings for CEOs, we investigate whether CEOs are willing to voluntarily issue negative earnings guidance to help prevent job termination. Of course, replacing a CEO is usually costly to shareholders because it involves a large amount of severance pay and uncertainty about the new hire's talent. So, it is likely that compensation committees keep CEOs who are more forthcoming. Trueman (1986) suggests that management forecasts signal the manager's ability to anticipate economic environment changes and to adjust business plans accordingly, so management forecast accuracy can be incorporated into the CEO retention decisions. Consistent with Trueman (1986), Lee, Matunaga, and Park (2010) document that the absolute management forecast error is significantly positively associated with the probability of CEO turnover. However, they only measure accuracy of the first management forecast, ignoring the fact that CEOs may update their forecast by issuing warnings. CEOs may issue warnings to update their previous forecasts with new information. If issuing warnings improves management forecast accuracy, it could reduce the

probability of CEO turnover. In addition, Mercer (2005) finds that CEOs who disclose bad news in a timely fashion experience an increased credibility among investors and this might have a positive effect on CEO turnover as well. Therefore, our hypothesis is stated as:

Hypothesis 7: Ceteris paribus, the probability of CEO turnover decreases if a warning is issued. 


\section{Sample Selection and Descriptive Statistics}

Our sample is based on the intersection of the ExecuComp, First Call, I/B/E/S, and Compustat databases from 1996 to 2005 . We start with year 1996 because the passage of the Private Securities Litigation Reform Act of 1995 changes the legal environment for firms disclosing forward-looking information. The sample period ends with 2005 because FAS123(R), which changes the reporting rules for executive compensation, takes effect from fiscal year after December $2005 .{ }^{10} \mathrm{We}$ collect warnings from First Call Company Issued Guidance. Consistent with warning studies by Kasznik and Lev (1995), Atiase, Supattarakul, and Tse (2006), Tucker (2007), and Tse and Tucker (2010), warnings are defined as negative earnings guidance (i.e., guidance that falls short of the existing market expectations) issued during the "confession window" (defined as the period between the beginning of the third month of a fiscal quarter and one day before earnings announcement date -- see figure 1).

The control firms (non-warning firms) for warning firms are chosen in a way similar to Tucker (2007). The non-warning firm years satisfy the following two requirements: (1) a firm does not warn during any quarter of a fiscal year; (2) within that year, there is at least one fiscal quarter during which the actual earnings are lower than analyst consensus forecast before the third fiscal month of the quarter (i.e., the confession window). This process yields a total of 6,947 firm-year observations with all necessary data from Compustat, First Call, I/B/E/S, and CRSP. Among all observations, 1,218 are warning observations and 5,729 are non-warning control observations. Table 1 presents the sample distribution of warning firms and non-warning control firms. All tests related to warning effects are based on this sample.

Table 1, Panel A reports that firm years are distributed approximately evenly throughout the sample years and warning firms account for $18 \%$ of total sample firms. Panel B of Table 1 tabulates the top

\footnotetext{
${ }^{10}$ The FASB issued FAS 123-R in December 2004, requiring the recognition of cost of the equity based compensation using fair value based measurement. This new regulation could result in increased compensation expenses, and firms may avoid this adverse effect by (1) avoiding new option grants; (2) accelerating the vesting of existing options; (3) shifting from stock option to restricted stock compensation (Carter, Lynch, and Tuna 2007). If firms choose the first solution, they may increase the bonus grants in order to make up the total compensation. As a result, it could introduce systematic noise into our study.
} 
twenty industries with the largest number of warnings where industries are classified according to twodigit SIC code. It shows that almost all industries issue warnings although chemical industry, machinery, electronic equipment, business services and instruments are the industries where most warnings are issued. The non-warning firms are almost proportionally distributed as are warning firms. Table 1, Panel $\mathrm{C}$ describes the main variables used in the empirical tests on CEO bonuses. Compared to non-warning firms, warnings firms experience greater bonus reduction, lower ROA growth, and lower annual cumulative returns. In addition, they are more likely to miss last year's earnings, experience lower quarterly earnings surprises and lower sales growth. Overall, the summary statistics indicate that warnings firms perform, on average, worse than non-warnings firms. Table 2 presents the correlation matrix for main variables.

Table 3 shows the descriptive statistics and correlation matrix for the variables used in testing options. Because of the new data requirement, the sample size for testing option grants is reduced to 6,733 from 6,947 firm-year observations, but the sample distributions across years are about the same (Table 3, Panel A). Regarding the three measures of option grants, T-statistics indicate that they are not significantly different between warning firms and non-warning firms. As for control variables, it is shown that CEOs of warnings firms have greater increase in exercisable options ( $\triangle$ EXER_OPT) and greater reduction in cash pay $(\triangle \mathrm{CASH})$. Compared to non-warning firms, warning firms also experience lower sales growth $(\triangle \mathrm{SIZE})$, smaller growth opportunities $(\triangle \mathrm{MB})$, and deeper reduced market returns $(\triangle \mathrm{RET})$. Moreover, warning firms become more cash constrained ( $\triangle \mathrm{CASH} C S T)$, earnings constrained ( $\left.\triangle \mathrm{EARN} \_\mathrm{CST}\right)$, more leveraged $(\triangle \mathrm{LEV})$, and riskier ( $\left.\triangle \mathrm{RISK} \_\mathrm{ID}\right)$. The correlation matrix of these variables is documented in Panel C of Table 3.

Panel A of Table 4 reports that there are 4,369 firm-year observations after merging our initial sample with the turnover sample from Hazarika, Karpoff, and Nahata (2011). ${ }^{11}$ Turnover observations

\footnotetext{
${ }^{11}$ The reduction of sample size is due to the fact that Hazarika, Karpoff, and Nahata (2011) study the CEO turnover and earnings management, so they only collect CEO turnover information for the observations for which the earnings management information is available.
} 
account for $11.88 \%$ of total observations. The cross-tabulation of the number of warning firms and the number of turnovers shows that $11.25 \%$ of non-warnings firms experience CEO turnover, while $14.58 \%$ of warning firms experience CEO turnover. The two-sample proportion test is significant $(\mathrm{Z}$-stat=2.67). As illustrated in Panel B, warning firms have lower adjusted accounting-based returns and stock returns, lower adjusted earnings surprises, and higher stock volatility, and are more likely to be in more concentrated industries.

The sample for testing the warning effect is also the initial sample for testing turnover hypothesis. Since ExcuComp does not specify the actual announcement of CEO turnover, we use the hand collected turnover data from Hazarika, Karpoff, and Nahata (2011). Merging the two samples provides 4,369 firmyear observations for testing turnover hypothesis. ${ }^{12}$ According to Hazarika, Karpoff, and Nahata (2011), they search the Factiva and Lexis-Nexis databases to locate the announcement date for each turnover. ${ }^{13}$

\section{Research Design and Empirical Results}

\subsection{Testing the Effect of Warnings on CEO Compensation and Pay-Performance Sensitivity}

\subsubsection{Research Design of Baseline Model}

Our first two hypotheses are about whether CEO bonus compensation and return-sensitivity are affected by warnings. Our baseline regression estimates the change in bonus as a function of warnings (WARN) after controlling for other determinants of bonus but without self-selection taken into account: ${ }^{14}$

$$
\begin{aligned}
\Delta \ln \left(\text { BONUS }_{\mathrm{it}}\right)= & \beta_{0}+\beta_{1} \Delta \mathrm{ROA}_{\mathrm{it}}+\beta_{2} \mathrm{RET}_{\mathrm{it}}+\beta_{3} \Delta \mathrm{ROA}_{\mathrm{it}} \times \mathrm{WARN}_{\mathrm{it}}+\beta_{4} \mathrm{RET}_{\mathrm{it}} \times \mathrm{WARN}_{\mathrm{it}} \\
& +\beta_{5} \mathrm{WARN}_{\mathrm{it}}+\beta_{6} \mathrm{NEWS}_{\mathrm{it}}+\beta_{7} \mathrm{SURPRISE}_{\mathrm{it}}+\beta_{8} \Delta \mathrm{SALE}_{\mathrm{it}}+\beta_{9} \mathrm{LEV}_{\mathrm{it}} \\
& +\beta_{10} \mathrm{MB}_{\mathrm{it}}+\beta_{11} \mathrm{TENURE}_{\mathrm{it}}+\beta_{12} \mathrm{CHAIR}_{\mathrm{it}}+\varepsilon_{\mathrm{it}}
\end{aligned}
$$

\footnotetext{
12 Their sample year ends in 2004, so we hand collected 2005 turnover data.

${ }^{13}$ See Hazarika, Karpoff, and Nahata (2011) for the details on their data collection procedures.

${ }^{14}$ Two recent studies by Francis, Lennox, and Wang (2010) and Larcker and Rusticus (2010) raise the concern that self-selection models are sometimes sensitive to model specifications and the property of the instrument variables in the first stage. Both papers suggest that OLS results are more reliable when self-selection model is less robust. Therefore, we present both OLS and self-selection models for most of the hypothesis testing in this paper.
} 
The dependent variable is the change in the natural logarithm of CEO bonus plus 1 . The main variable of interest is WARN, an indicator variable, which equals one when a firm issues a warning (warnings) in any quarter of the fiscal year, zero otherwise.

We control for both accounting-based return $(\triangle \mathrm{ROA})$ and market-based return (RET) (Lambert and Larcker 1987; Sloan 1993). Following the literature, we further control for firm characteristics that are likely to affect CEO compensation and pay-performance sensitivity, such as firm size (Smith and Watts 1992; Farrell and Whidbee 2003), leverage (Leone, Wu, and Zimmerman 2006), market-to-book ratio (Leone, Wu, and Zimmerman 2006), and two measures of CEO entrenchment (Core, Holthausen, and Larcker 1999): TENURE and CHAIR. In addition, Matsunaga and Park (2001) find that CEOs' annual bonus will be adversely affected if earnings fall short of earnings for the same quarter of last year for at least twice during the year. Therefore, we include NEWS (defined as 1 if this year's EPS excluding extraordinary items is lower than last year' EPS, zero otherwise) in order to account for the negative effect of missing an earnings benchmark on bonus. ${ }^{15}$

Warnings are issued when managers' expectation of forthcoming earnings is lower than the market consensus. Thus, to warn or not to warn becomes irrelevant when managers are expecting a positive earnings surprise. It is for this reason that our control sample for testing warning effects includes only firms that have experienced a negative earnings surprise in at least one quarter of that fiscal year. In addition, as another step to control for the factors that affect the decision to warn, we include SURPRISE, which is defined through two steps as follows. First, we calculate the difference between the actual EPS and the most recent consensus analyst forecast one day before the first day of the third month of a fiscal quarter (i.e., one day before the confession window), scaled by the beginning-quarter share price for each quarter of the year. ${ }^{16}$ Second, we take the lowest quarterly value (i.e., the most negative earnings surprise)

\footnotetext{
${ }^{15}$ As reported in sensitivity tests, we include all the earnings benchmark variables used in Matsunaga and Park (2001) and the results remain qualitatively the same.

${ }^{16} \mathrm{We}$ measure analyst consensus forecasts one day before the third month of the fiscal quarter because warnings are issued after the beginning of the third month of the fiscal quarter (the "confession window"). Therefore, this measure captures the difference between management and market expectations before the confession window.
} 
from the previous step because warnings are most likely to occur in the quarters where the surprise is most negative. $^{17}$

$\beta_{5}$ is the coefficient of interest when testing $H 1$. An insignificant $\beta_{5}$ suggests that warnings have no impact on CEO bonus, while $\beta_{5}<0\left(\beta_{5}>0\right)$ indicates a negative (positive) effect of issuing a warning on $\mathrm{CEO}$ bonus growth. As argued in $H 2$, warning firms' sensitivity of bonus to stock returns is expected to be higher than that of non-warning firms, or $\beta_{4}>0$.

In estimating equation (1), we follow Core, Guay, and Verrecchia (2003) so that our baseline model includes year indicators to account for the year-specific differences in the level of compensation, e.g., the time trend in annual pay (Murphy 1999), and industry indicators to control for unobserved variations in the CEO pay across industries: e.g., different demand for managerial talent across industries (Murphy 1999). In addition, because we estimate equation (1) using panel data, there may be within-firm errorterm time-series correlations. Ignoring this serial correlation could lead to underestimated standard errors and overestimated t-statistics (Cameron and Trivedi 2005). Therefore, we estimate standard errors using Huber-White correction with clusters at the firm level.

\subsubsection{Research Design of Self-Selection Model}

The decision to warn or not to warn is discretionary. CEOs make this decision based on a number of considerations, which we later proxy with a series of variables, including firm characteristics. However, these variables may also affect CEO pay. Thus, without controlling for CEOs' "self-selection" as to warn or not to warn, findings in the baseline model could be driven by these variables or the unobserved variables that affect the decision to warn. Following Tucker (2007), we run a two-stage Heckman (1979) model with separate Inverse Mills Ratios (IMR) for warning firms and non-warning firms (See model specification in Appendix A, Part 1). In the first stage, we estimate the following probit regression of the decision to warn:

\footnotetext{
${ }^{17}$ This measure also addresses the concern that some firms may have previously provided guidance and the market consensus is similar to the management's expectation at the beginning of the warning window examined in the study.
} 


$$
\begin{aligned}
& \operatorname{Pr}\left(\mathrm{WARN}_{\mathrm{it}}=1\right)=\Phi\left(\alpha_{0}+\alpha_{1} \mathrm{RISK}_{\mathrm{it}}+\alpha_{2} \mathrm{LN} \_\mathrm{MVE}_{\mathrm{it}}+\alpha_{3} \mathrm{UPDATE} \_\mathrm{GUDE} \mathrm{it}_{\mathrm{it}}\right.
\end{aligned}
$$

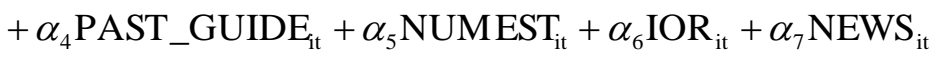

$$
\begin{aligned}
& \left.+\alpha_{8} \mathrm{SURPRISE}+\alpha_{9} \mathrm{MB}_{\mathrm{it}}+\alpha_{10} \mathrm{ROA}_{-} \mathrm{STD}_{\mathrm{it}}+\alpha_{11} \mathrm{FD}_{\mathrm{it}}+\varepsilon_{\mathrm{it}}\right)
\end{aligned}
$$

In the second stage, we calculate IMRs for warning groups $\left(\frac{\phi\left(Z_{i t}^{\prime} \gamma\right)}{\Phi\left(Z_{i t}^{\prime} \gamma\right)}\right)$ and non-warning groups $\left(\frac{-\phi\left(Z_{i t}^{\prime} \gamma\right)}{1-\Phi\left(Z_{i t}^{\prime} \gamma\right)}\right)$ and update the baseline model by adding these two self-selection ratios:

$$
\begin{aligned}
\Delta \ln \left(\mathrm{BONUS}_{\mathrm{it}}\right) & =\beta_{0}+\beta_{1} \Delta \mathrm{ROA}_{\mathrm{it}}+\beta_{2} \mathrm{RET}_{\mathrm{it}}+\beta_{3} \Delta \mathrm{ROA}_{\mathrm{it}} \times \mathrm{WARN}_{\mathrm{it}}+\beta_{4} \Delta \mathrm{RET}_{\mathrm{it}} \times \mathrm{WARN}_{\mathrm{it}} \\
& +\beta_{5} \mathrm{WARN}_{\mathrm{it}}+\beta_{6} \mathrm{NEWS}_{\mathrm{it}}+\beta_{7} \mathrm{SURPRISE}_{\mathrm{it}}+\beta_{8} \Delta \mathrm{SALE}_{\mathrm{it}}+\beta_{9} \mathrm{LEV}_{\mathrm{it}} \\
& +\beta_{10} \mathrm{MB}_{\mathrm{it}}+\beta_{11} \mathrm{TENURE}_{\mathrm{it}}+\beta_{12} \mathrm{CHAIR}_{\mathrm{it}}+\beta_{13} \mathrm{IMR}_{\mathrm{it}} * \mathrm{WARN}_{\mathrm{it}} \\
& +\beta_{14} \mathrm{IMR}_{\mathrm{it}} *\left(1-\mathrm{WARN}_{\mathrm{it}}\right)+\varepsilon_{\mathrm{it}}
\end{aligned}
$$

Note we estimate equation (2) using annual data, while Tucker (2007) uses quarterly data. To control for general litigation risk, we include the predicted risk of being sued (RISK), the size of the firm (LN_MVE), and UPDATE_GUIDE to measure whether a firm has provided guidance before the third fiscal month of the quarter and the necessity for CEOs to update the previous guidance. CEOs' reputation concern may also affect their decision to warn. If a firm frequently issued guidance in the last year, it is more likely to warn if the performance is poor in the current year (PAST_GUIDE). A larger number of analysts (NUMEST) are likely to impose a more transparent information environment for a firm and managers may be more forthcoming (Lang and Lundholm 1996a). Two earnings performance measures are also included, NEWS and SURPRISE, as a firm is more likely to warn when it misses last year's earnings benchmark, and when the market consensus is much lower than the managers' expectation of the impending earnings. In addition, we include market-to-book ratio (MB) to differentiate growth firms from other firms. Earnings volatility (ROA_STD) is also included since Tucker (2007) shows that firms with more volatile earnings find less need to warn. In addition, we include the number of institutional holdings (IOR) because managers are more likely to issue earnings guidance when institutional holdings increase (Anilowski, Feng, and Skinner 2007). Heflin, Subramanyam, and Zhang (2003) report evidence that the volume of firms' earnings-related forward-looking disclosures increases after the implementation of 
Regulation Fair Disclosure (hereafter Regulation FD). On the other hand, Wang (2007) demonstrates that firms that relied on private earnings guidance replace it with no guidance instead of public guidance after Regulation FD. We include an indicator variable, FD, to account for this regulation effect, but do not assign an expected sign. In summary, we expect that positive relations between the probability to warn and the following variables: RISK, LN_MVE, UPDATE_GUIDE, PAST_GUIDE, NUMEST, IOR and NEWS. We expect negative relations between the probability to warn and SURPRISE, MB, and ROA_STD. Variable definitions are presented in Table 5. All variables in equation (3) are defined as in equation (1).

\subsubsection{Research Design: Effect of Warnings on CEO Option Grants and Option-Performance Sensitivity}

We follow the specification in Cheng and Farber (2008) to test the changes in option grants after warnings are issued. Similar to the test of the changes in CEO bonus, this test adopts a difference-indifference approach where all variables are calculated as the difference between year $\mathrm{t}$ and $\mathrm{t}-1$ except the variable of interest (WARN) issued in year t. We use three measures of stock-based compensation awards: the natural logarithm of Black-Scholes value of annual option grants, the natural logarithm of the actual number of option grants, and the ratio of the Black-Scholes value of option grants to the total annual compensation, denoted as $\ln (\mathrm{OPTION} \$), \ln (\mathrm{OPTION \#})$, and OPTION\%, respectively. ${ }^{18}$ Control variables include CEO ownership (SHARES_OWN, EXERC_OPT), standard determinants of compensation (SIZE, BM, RD, RET), choice between cash compensation and equity compensation (CASH_CST, EARN_CST, CASH), and agency cost (LEV, RISK_ID) and are discussed next.

Prior studies find that when CEOs' equity holding is low, firms often adjust compensation structure by awarding more stocks and options (Core, and Guay 1999; Bryan, Hwang, and Lilien 2000). To measure CEO ownership, we use two proxies: the actual number of shares owned (SHARES_OWN) and the number of exercisable options (EXER_OPT), both of which are scaled by the number of outstanding

\footnotetext{
${ }^{18}$ To avoid taking the natural logarithm of zero, we add 1 to both OPTION\$, and OPTION\# before taking the natural logarithm.
} 
shares. ${ }^{19}$ As firm size increases, the business becomes more complex to require more talented CEOs with high compensation. In addition, larger firms are more difficult to monitor, and to reduce the potential agency conflict, firms use more incentive compensation plan (Smith and Watts 1992; Core and Guay 1999). Thus, we include the natural logarithm of sales as a measure of firm size (SIZE). Similarly, firms with greater growth opportunities are likely to rely on incentive compensation to align the interests of CEOs and shareholders (Myers 1977; Smith and Watts 1992; Bryan, Hwang, and Lilien 2000). We, therefore, include market-to-book (MB) and research and development expenditures (RD) as proxies for growth opportunities, but we make no prediction regarding the sign of the coefficient on RD because evidence on RD and stock-based compensation is mixed (Cheng and Farber 2008). CEO compensation is positively associated with performance measures, and we include stock returns (RET) to measure firm performance (Baber, Janakiraman, and Kang 1996).

Firms with cash constraints tend to use stock-based compensation more heavily (Yermack 1995). To measure cash constraints, we use common and preferred dividends minus cash flows in investment activities minus cash flows from operating activities, divided by total assets (CASH_CSTR). During the sample period, firms are not required to recognize expenses when options are granted at the market value and consequently, firms with earnings lower than threshold earnings prefer to grant options for financial reporting purposes. Therefore, following Chen and Farber (2008), we include earnings constraints (EARN_CSTR), measured as an indicator variable of operating loss, to account for the advantage of using option compensation over cash compensation. Guay (1999) argues that greater cash compensation reduces the need for using option grants to encourage CEOs to invest in risky and positive NPV projects because more cash compensation enables CEOs to better diversify their risks. We include total cash compensation divided by sales (CASH) as another control variable. However, the evidence on the relation

\footnotetext{
${ }^{19}$ Options are excluded when calculating SHARES_OWN to avoid a mechanical relation between SHARES_OWN and the new option grants. We include the number of options (EXER_OPT) to account for the existing options granted in previous years. This variable is less likely to create a mechanical relation with the dependent variable because new options usually are not exercisable until several years later. Because Compustat includes new grants as unexercisable, we do not use it as a control variable.
} 
between earnings constraints and option grants and that between cash compensation and option grants is not conclusive, so we do not assign signs for these two variables.

Since shareholders benefit more from incentives-based compensation than debtholders (Bryan, Hwang, and Lilien 2000), highly-leveraged firms (greater shareholder-debtholder conflicts) will have incentives to reduce stock-based compensation. We measure leverage (LEV) as long-term debt over total assets. Idiosyncratic risk (RISK_ID) is also added to the model because greater RISK_ID means that a firm is more difficult to monitor. RISK_ID is measured as the standard deviation of the residual from the market model using weekly returns over the past 12 months. The model also includes year and industry dummies and estimates the statistical significance using Huber/White robust standard errors to adjust for heteroscedasticity and within-firm time-series correlation. To test hypothesis 3 and 4 , we estimate the following model after controlling for self-selection:

$$
\begin{aligned}
\Delta\left(\mathrm{OPTION}_{\mathrm{it}}\right) & =\beta_{0}+\beta_{1} \mathrm{WARN}_{\mathrm{it}}+\beta_{2} \Delta \mathrm{RET}_{\mathrm{it}} \times \mathrm{WARN}_{\mathrm{it}}+\beta_{3} \Delta \mathrm{SHARES} \_\mathrm{OWN} \\
& +\beta_{5} \Delta \mathrm{SIZE}_{\mathrm{it}}+\beta_{6} \Delta \mathrm{MB}_{\mathrm{it}}+\beta_{7} \Delta \mathrm{RD}_{\mathrm{it}}+\beta_{8} \Delta \mathrm{RET}_{\mathrm{it}}+\beta_{9} \Delta \mathrm{CASH}_{-} \mathrm{CST}_{\mathrm{it}} \\
& +\beta_{10} \Delta \mathrm{EARN}_{\mathrm{it}} \\
& \left.+\beta_{15} \mathrm{IMR}_{\mathrm{it}}+\beta_{11} \Delta \mathrm{CASH}_{\mathrm{it}}+\beta_{12} \Delta \mathrm{LEV}_{\mathrm{it}}+\beta_{13} \Delta \mathrm{RISK}_{\mathrm{it}} \mathrm{ID}_{\mathrm{it}}+\beta_{14} \mathrm{IMR}_{\mathrm{it}} * \mathrm{WARN}_{\mathrm{it}}\right)+\varepsilon_{\mathrm{it}}
\end{aligned}
$$

Hypothesis 3 and 4 predict that both $\beta_{1}$ and $\beta_{2}$ are positive and significant, suggesting that warning CEOs tend to receive more option grants than do non-warning CEOs.

\subsubsection{Test Results on CEO Compensation}

Table 5 presents the first-stage probit analysis of the decision to warn. The overall model explanatory power is $10.1 \%$, comparable to the $9.15 \%$ in Tucker (2007). As expected, firms are more likely to warn if they have a higher probability of being sued, have previously issued guidance in the event quarter, frequently issued guidance in the last year, have more analysts following the firm, have higher institutional holding, have experienced an earnings shortfall, have suffered a bigger negative earnings surprise, and have lower earnings volatility. Consistent with Wang (2007), we find a negative sign on FD, although not significant. Contrary to the prediction, however, LN_MVE and MB are both 
significantly negative, suggesting that larger firms and growth firms tend not to warn. ${ }^{20} \mathrm{~A}$ concurrent working paper by Lee, Matsunaga, and Park (2010), which uses a sample similar to our study, also shows a significant negative coefficient on firm size when predicting the decision to issue management guidance.

Table 6 reports the regression results for both the baseline and the self-selection models for bonus compensation. Since all the variables that are significant in the baseline model remain significant except RET*WARN ( -value=0.115), our discussion focuses on the model with self-selection. Warnings have an incremental, negative effect on the change in CEO bonus $\left(\beta_{5}=-1.845\right.$ with $\mathrm{p}$-value $\left.=0.000\right)$, indicating that CEO bonuses will be adversely affected if a warning is issued during that year. CEO bonuses are negatively affected presumably because compensation committees find that warning signals reveal information beyond the reported firm performance measures. In particular, it signals potential long-term earnings losses. It may also be possible that the negative market reaction to warnings concerns compensation committees (Matsunaga and Park 2001) and CEOs' bonuses are reduced for this unfavorable situation.

The coefficient on RET*WARN is positive, although not significant after adding self-selection terms for warning and non-warning groups. ${ }^{21}$ The coefficient on self-selection term is an estimate of the product of the standard deviation of the error term in equation (1) and the correlation between the error term in equation (1) and the error in equation (2). The coefficient on the Inverse Mills ratio for warning firms $(\mathrm{IMR} * \mathrm{WARN})$ is significantly positive $\left(\beta_{13}=0.814\right.$ with $\mathrm{p}$-value $\left.=0.002\right)$, indicating that unobserved factors that increase the likelihood of warning lead to an increase in bonus growth. One example of these unobserved factors could be CEOs' reputation. That is, a CEO who is concerned with his/her reputation is

\footnotetext{
${ }^{20}$ This may be caused by two reasons. (1) Our sample firms are significantly larger than Tucker's (2007) as the median size of warning firms and non-warnings firms is \$1267.13 (432) millions and \$1634.00 (226) millions in our study (in her study). Evidence provided in Wang (2007) suggests that larger firms were more likely to provide private earnings guidance before Regulation FD was enacted. (2) Our sample period has three more years in the post FD environment than Tucker (2007). Wang (2007) also shows that after Regulation FD, firms that used to rely more on private guidance stopped providing guidance rather than start to issue public guidance.

${ }^{21}$ We do not draw any conclusive inference here because this coefficient becomes significant with $\mathrm{p}$-value $=0.015$ once we include RPE measures in Table 6. We discuss this change in significant levels in section 4.2.
} 
more likely to issue warnings, ceteris paribus, and the reputation is positively correlated with bonus growth. As a result, after controlling for this effect, the coefficient on WARN changes from -0.685 to 1.845. There is no self-selection effect on non-warnings groups ( $\beta_{14}$ has a p-value of 0.652$)$.

As to control variables, both firm performance measures, $\triangle \mathrm{ROA}$ and RET, are significantly positively related to changes in bonus. The coefficient on $\triangle \mathrm{ROA} * \mathrm{WARN}$ is insignificant at the conventional level, which suggests that warnings do not affect the sensitivity of bonus to accounting measures. Consistent with Matsunaga and Park (2001), CEO cash bonuses are penalized when current year's earnings fall below that of the previous years $\left(\beta_{6}=-0.743\right.$ with $\mathrm{p}$-value $\left.=0.000\right)$. We do not find a significant result on SURPRISE. It might be caused by its high correlation with other performance measures as Table 2 shows that it has a significantly positive correlation with $\triangle$ ROA, RET, and $\triangle \mathrm{SALE}$ and a significantly negative correlation with NEWS. As expected, we find that an increase in sales leads to an increase in cash bonus, and consistent with Albuquerque (2009), we find that CEO bonus growth is higher for less experienced CEOs.

Next, we discuss the results of the regression analysis on CEO option compensation. Table 7 uses all three option grant measures to test whether warning firms grant more options than do non-warning firms. Specifically, the coefficients on $\ln ($ OPTION\$), $\ln ($ OPTION\#), and OPTION\% are 0.577 (pvalue $=0.054), 0.615(\mathrm{p}$-value $=0.008)$ and $1.180(\mathrm{p}$-value $=0.004)$, respectively, suggesting that changes in the value of option grants, changes in the number of option grants, and changes in the percentage of compensation from stock options are all significantly higher for warning firms than for non-warning firms. The coefficients on $\triangle \mathrm{RET} * \mathrm{WARN}$, however, are insignificant across all three measures for option grants, indicating that the sensitivity of option grants to stock returns does not differ between warning and non-warning firms, counter to the hypothesized relation. In general, most control variables with predicted signs appear as expected. More specifically, compensation from stock options is greater for firms with lower level of CEO ownership, better performance, and less debt. The coefficients on IMR*WARN are all negative and significant at the conventional level, indicating that unobservable factors that lead 
managers to issue warnings negatively affect CEO option grants. Collectively, the results lend support to Hypothesis 3 that warning firms tend to grant more options $(\ln (\mathrm{OPTION} \$), \ln (\mathrm{OPTION} \#))$ than do nonwarning firms, and warning firms' compensation structure (OPTION\%) changes toward more equitybased compensation from cash-based compensation. A word of caution seems appropriate regarding the inference of the option grants. Options can be granted anytime during the year. Hence, although we establish an association, ideally, we would need to check whether the options are granted after warnings are issued to establish causality. Option grant dates are not required to be disclosed, so the duration and the expiration dates from proxy statement need to be collected in order to infer the option grant dates.

\subsection{The Effect of Peer Firms' Warnings on a Firm's Pay-Performance Sensitivity}

\subsubsection{Research Design}

In the context of RPE, Holmstrom and Milgrom (1987) model the managers' compensation contract as a linear function of several variables. Denote $x_{1}, x_{2}$, and $w$ as the performance of a firm, the aggregate performance of this firm's peers, and the compensation of this firm's manger, respectively. Then, $w=\alpha+\beta_{1} x_{1}+\beta_{2} x_{2}$. The weak form of RPE tests whether $\beta_{2}<0$ and the strong form RPE tests whether $\beta_{2} / \beta_{1}=-\rho \cdot{ }^{22}$ Equation (5) below tests the conventional RPE (i.e., the effect of peers' accounting-based returns and stock returns) and our measure of RPE (i.e., the effect of peers' warnings on a firm's pay-performance sensitivity) for CEO bonus. ${ }^{23}$

\footnotetext{
${ }^{22}$ Empirical tests of RPE have been conducted in two different ways: strong form and weak form. However, the strong form test assumes that a firm's effort has no effect on the expected performance of its peer firms and this is hardly to be true because of the well-known strategic interaction among firms in the industry. As a result, consistent with the majority of RPE studies, we use the weak form test to examine how RFE affects the effect of warnings and tip-offs on CEO's bonus.

${ }^{23}$ WARN*PEERW, $\triangle$ ROA*PEERW, and RET*PEERW are mechanically perfectly correlated with PEERW, $\triangle$ ROA*WARN*PEERW, and RET*WARN*PEERW. Thus, WARN*PEERW, $\triangle$ ROA*PEERW, and RET*PEERW are not included in model (5).
} 


$$
\begin{aligned}
& \Delta \ln \left(\mathrm{BONUS}_{\mathrm{it}}\right)=\beta_{0}+\beta_{1} \Delta \mathrm{ROA}_{\mathrm{it}}+\beta_{2} \mathrm{RET}_{\mathrm{it}}+\beta_{3} \Delta \mathrm{ROA}_{\mathrm{it}} \times \mathrm{WARN}_{\mathrm{it}}+\beta_{4} \mathrm{RET}_{\mathrm{it}} \times \mathrm{WARN}_{\mathrm{it}} \\
& +\beta_{5} \Delta \mathrm{ROA}_{\mathrm{it}} \times \mathrm{WARN}_{\mathrm{it}} \times \mathrm{PEERW}_{\mathrm{it}}+\beta_{6} \mathrm{RET}_{\mathrm{it}} \times \mathrm{WARN}_{\mathrm{it}} \times \mathrm{PEERW}_{\mathrm{it}}+\beta_{7} \mathrm{WARN}_{\mathrm{it}} \\
& +\beta_{8} \text { PEERW }_{\mathrm{it}}+\beta_{9} \text { RPE_ } \triangle \mathrm{ROA}+\beta_{10} \mathrm{RPE} \_\mathrm{RET}+\beta_{11} \mathrm{NEWS}_{\mathrm{it}}+\beta_{12} \mathrm{SUR}_{-} \mathrm{MIN} \_\mathrm{ADI} \mathrm{it}_{\mathrm{it}} \\
& +\beta_{13} \Delta \mathrm{SALE}_{\mathrm{it}}+\beta_{14} \mathrm{LEV}_{\mathrm{it}}+\beta_{15} \mathrm{MB}_{\mathrm{it}}+\beta_{16} \mathrm{TENURE}_{\mathrm{it}}+\beta_{17} \mathrm{CHAIR}_{\mathrm{it}} \\
& +\beta_{18} \mathrm{IMR}_{\mathrm{it}} * \mathrm{WARN}_{\mathrm{it}}+\beta_{19} \mathrm{IMR}_{\mathrm{it}} *\left(1-\mathrm{WARN}_{\mathrm{it}}\right)+\varepsilon_{\mathrm{it}}
\end{aligned}
$$

Following Albuquerque (2009), RPE__ROA is defined as the equally-weighted change in ROA portfolio of peer firms in the same two-digit SIC code and size quartile, excluding the firm itself. Similarly, RPE_RET is calculated as the equally-weighted cumulative stock return portfolio of peer firms in the same two-digit SIC code and size quartile, excluding the firm itself. PEERW measures the number of peer firms that issue warnings. The following three steps are taken to define PEERW. ${ }^{24}$

Step 1: Similar to Tucker (2007), a firm's fiscal quarter is relabeled to the calendar quarter with which it overlaps most. ${ }^{25}$ This process, called calendarization, is to account for the fact that only twothirds of firms in an industry end their fiscal quarters in the same month.

Step 2: We locate all warning firms within the peer group, defined as in Albuquerque (2009), which are in the same two-digit SIC code, the same size quartile, and the same calendar quarter of the year.

Step 3: Since CEO cash compensation is annualized data, we convert quarterly warning peers from Step 2 to annual warning peers as follows: (1) for a warning firm, the total number of warning peers (PEERW) is the aggregate number of unique peers during the year. To illustrate, if a firm issues a warning in the first quarter with two warning peers, firms A and B, and the third quarter with three peers, firms B, C, and D in a year, then four (A, B, C, and D) will be taken as the number of warning peers for that year; (2) the total number of warning peers is set to zero for all non-warning firms. All other variables are as defined previously.

With respect to warning firms, the sum of $\beta_{2}$ and $\beta_{4}\left(\beta_{2}+\beta_{4}\right)$ measures the effect of bonus sensitivity to stock returns when a warning firm does not have warning peers. More directly related to our

\footnotetext{
${ }^{24}$ There are two sub-groups among warning firms: (1) warning firms with warning peers, i.e., a few peers also issued earnings warnings in the same quarter, and (2) warning firms without warning peers. Peers are defined as firms in the same market size quartile and from the same industry.

${ }^{25}$ For example, the third calendar quarter includes the fiscal quarters that end in August, September, and October of that year.
} 
hypothesis, $\beta_{6}$ captures the incremental effect of warnings on the sensitivity of bonus to stock returns when a warning firm has one additional peer that also issues warnings. As the number of peer firms increases, the magnitude of such effect increases. $H 3$ predicts that the more peers issue warnings, the lower the bonus sensitivity to stock returns, suggesting $\beta_{6}<0$.

To test the effect of peer warnings on the sensitivity of option grants to stock returns, we augment the previous model (4) by adding the number of peer firms that issue warnings (PEERW), and interact it with $\triangle \mathrm{RET}(\triangle \mathrm{RET} * \mathrm{WARN} *$ PEERW $)$ as follows. ${ }^{26}$

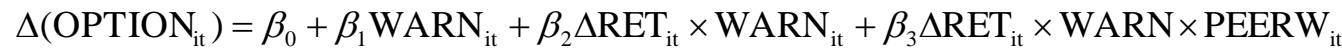

$$
\begin{aligned}
& +\beta_{4} \text { PEERW }_{\mathrm{it}}+\beta_{5} \Delta \text { SHARES_OWN }{ }_{\mathrm{it}}+\beta_{6} \Delta \mathrm{EXER} \_O P T_{\mathrm{it}}+\beta_{7} \Delta \mathrm{SIZE}_{\mathrm{it}} \\
& +\beta_{8} \Delta \mathrm{MB}_{\mathrm{it}}+\beta_{9} \Delta \mathrm{RD}_{\mathrm{it}}+\beta_{10} \Delta \mathrm{RET}_{\mathrm{it}}+\beta_{11} \Delta \mathrm{CASH} \_\mathrm{CST} \mathrm{it}_{\mathrm{it}}+\beta_{12} \Delta \mathrm{EARN}_{-} \mathrm{CST} \mathrm{it}_{\mathrm{it}} \\
& +\beta_{13} \Delta \mathrm{CASH}_{\mathrm{it}}+\beta_{14} \Delta \mathrm{LEV}_{\mathrm{it}}+\beta_{15} \Delta \mathrm{RISK}_{-} \mathrm{ID}_{\mathrm{it}}+\beta_{16} \mathrm{IMR}_{\mathrm{it}} * \mathrm{WARN}_{\mathrm{it}} \\
& +\beta_{17} \mathrm{IMR}_{\mathrm{it}} *\left(1-\mathrm{WARN}_{\mathrm{it}}\right)+\varepsilon_{\mathrm{it}}
\end{aligned}
$$

Hypothesis 6 predicts that the sensitivity of option grants to stock returns of warning firms decreases as the number of warning peers increases. Therefore, we expect a negative coefficient on $\triangle$ RET*WARN*PEERW $\left(\beta_{3}<0\right)$.

\subsubsection{Test Results}

We discuss the results of the models controlling for self-selection since OLS results have the same inferences. Table 5, the last column shows the testing results of H5. First, we find the evidence of RPE based on the conventional RPE measure. Specifically, consistent with Gibbons and Murphy (1990), Janakiraman, Lambert, and Larcker (1992), and Albuquerque (2009), the coefficient on RPE_RET is significantly negative $\left(\beta_{10}=-0.368\right.$ with $\mathrm{p}$-value $\left.=0.006\right)$, providing evidence that peer firms' stock returns are filtered out from the CEO bonus. Not surprisingly, RPE_ $\triangle \mathrm{ROA}$ is positive and significant as documented in Albuquerque (2009), indicating that accounting-based return is not used to filter out the

\footnotetext{
${ }^{26}$ As PEERW represents the number of warning peers, $\triangle \mathrm{RET} * \mathrm{WARN} *$ PEERW $=\Delta$ RET $*$ PEERW. In untabulated results, we also include equal-weighted change in ROA and change in return of peer firms that are in the same twodigit SIC and size quartile, excluding the own firm, as defined in Albuquerque (2009). These two variables are insignificant, and all other results are qualitatively unaltered.
} 
noise or external shocks. ${ }^{27}$ As predicted in $H 2$, after controlling for peer performance measures and selfselection, warnings affect the bonus sensitivity to stock returns as demonstrated by the significantly positive coefficient on RET*WARN (p-value=0.015). This indicates that CEO-bonus sensitivity to stock returns is higher for warning firms than for non-warning firms. Furthermore, the coefficient on RET*WARN*PEERW $\left(\beta_{6}=-0.173\right)$ is significantly negative ( $\mathrm{p}$-value=0.040), consistent with the prediction of H5. The negative coefficient means that as more peer firms issue warnings, the compensation committees become more lenient towards CEOs because the warnings issued by peer firms indicate that there might be an industry-wide shock that leads to the negative earnings surprises.

Table 8 presents the results of estimating equation (6). The relations between the three measures of option grants $(\ln (\mathrm{OPTION} \$), \ln (\mathrm{OPTION})$, and OPTION\%)) and $\triangle \mathrm{RET} * \mathrm{WARN}$ *PEERW are all negative at $\mathrm{p}$-value $<0.01$. The coefficient on $\triangle \mathrm{RET} * \mathrm{WARN}$ is insignificant for $\ln (\mathrm{OPTION} \$)$ and $\ln (\mathrm{OPTION})$, suggesting that the sensitivity of option grants does not differ between warning firms and non-warning firms. Nevertheless, the negative coefficient on $\triangle$ RET*WARN*PEERW implies that, among warnings firms, the sensitivity of option grants to returns varies by the number of warning peers. That is, holding returns constant, warning firms with more warning peers will receive fewer option grants. Together with the results on bonus, these results indicate that the need to restructure CEO compensation is attenuated when peer CEOs also issue warnings. All other inferences remain the same as discussed in the previous section.

\subsection{Testing a Potential Benefit of Issuing Warnings: Reduced CEO Turnover}

The results of the first stage analysis of the decision to issue warnings show that there are a number of incentives for firms to issue warnings. To further validate the potential benefits of issuing warnings, we compare the litigation risk of warning firms and non-warning firms before the event year using our

\footnotetext{
${ }^{27}$ Albuquerque (2009) offers a potential explanation of the positive coefficient on peer firms' change in ROA. She argues that accounting numbers are based on the principle of conservatism and therefore the external shocks are already removed.
} 
sample. Table 9, Panel A reports that the predicted litigation risk is significantly higher for warnings firms than for non-warning firms in the years before warnings are issued ( $\mathrm{z}$-stat=3.425), consistent with the argument in Skinner $(1994,1997)$ that firms voluntarily disclose bad news to reduce litigation risk.

We also compare the analyst forecast errors before and after the confession window for warning firms and non-warning firms. In Table 9, Panel B, for 1,218 warnings firms, there are 1,486 individual quarterly warnings as some firms issue multiple warnings in a fiscal year. The mean analyst forecast error (AFE) before warnings and after warnings are -0.812 and -0.508 respectively, which are significantly different ( $\mathrm{t}-\mathrm{stat}=2.215)$. The forecast accuracy measured by the absolute value of forecast error (ABS(AFE)) shows supporting evidence that the forecast accuracy is significantly increased as well after warnings are issued because the absolute forecast error decreased from 0.815 to 0.527 ( $\mathrm{t}$-stat $=-2.098$ ). More intuitively, after warnings, $48.3 \%$ firms meet or beat analyst forecasts while only $3.7 \%$ would have done so if warnings were not issued; the change in the frequency of meeting or beating analyst forecasts is statistically significant with $\mathrm{t}$-stat=22.708. However, all these changes calculated for warning firms may not be due to warnings; they could be due to other systematic time trend. To control for that, we calculate the corresponding changes in analyst forecasts for non-warning firms and compare the changes for warning firms with those for non-warnings firms. Panel $\mathrm{C}$ of Table 9 shows that all three measures of changes significantly differ between warning and non-warning firms. In particular, comparing to quarters without warnings, firms with warnings experience a greater magnitude of decrease in negative earnings surprise ( $\mathrm{t}$-stat=3.861), an increase in forecast accuracy ( $\mathrm{t}$-stat=3.824), and an increase in the frequency of meeting or beating analyst forecast $(\mathrm{t}$-stat $=13.348) .{ }^{28}$ In a nut shell, these descriptive statistics support the arguments in the previous literature that firms issue warnings (1) to reduce litigation risk, (2) to reduce analyst forecast errors (by guiding them downward) and (3) to increase the likelihood of avoiding negative earnings surprises. These benefits are likely to accrue to the warning firms as a whole. To see if

\footnotetext{
${ }^{28}$ Matsumoto (2002) argues that managers guide analysts' forecasts downward in order to meet or beat expectations at the earnings announcement date. Examining whether warnings are issued to meet or beat expectation is beyond the scope of this study.
} 
CEOs receive more CEO-specific benefits, we next examine whether CEOs turnover rate is affected by the issuance of warnings. Given that these firms tend to be performing poorly, we expect job retention to be an important concern for the CEOs.

\subsubsection{Research Design}

The model for testing the turnover hypothesis is based on DeFond and Park (1999). We augment the model by adding controls for earnings losses, CEO tenure, and earnings volatility. Specifically, we estimate the following model:

$$
\begin{aligned}
\operatorname{Pr}\left(\text { TURN }_{\mathrm{it}+1}\right) & =\Phi\left(\beta_{0}+\beta_{1} \mathrm{WARN}_{\mathrm{it}}+\beta_{2} \Delta \mathrm{ROA}_{-} \mathrm{ADJ}_{\mathrm{it}}+\beta_{3} \mathrm{RET}_{-} \mathrm{ADJ}_{\mathrm{it}}+\beta_{4} \mathrm{AGE}_{-} 63_{\mathrm{it}+1}\right. \\
& +\beta_{5} \mathrm{AGE}_{\mathrm{it}+1}+\beta_{6} \mathrm{LOSS}_{\mathrm{it}}+\beta_{7} \mathrm{FE} \_\mathrm{ADJ}_{\mathrm{it}}+\beta_{8} \mathrm{RETVAR}_{\mathrm{it}}+\beta_{9} \mathrm{TENURE}_{\mathrm{it}} \\
& \left.+\beta_{10} \mathrm{HHI}+\beta_{11} \mathrm{ROAVAR}+\beta_{12} \mathrm{IMR} \mathrm{WARN}_{\mathrm{it}}+\beta_{13} \mathrm{IMR} \times\left(1-\mathrm{WARN}_{\mathrm{it}}\right)+\varepsilon_{\mathrm{it}}\right)
\end{aligned}
$$

Hypothesis 7 predicts a reduced probability of CEO turnover after warnings are issued, i.e., $\beta_{1}<0$. TURN equals one if there is a CEO change in the following year, and zero otherwise. With regard to control variables, we use adjusted accounting-based returns and stock returns to filter out industry-peer effects (DeFond and Park 1999). In particular, $\triangle$ ROA_ADJ and RET_ADJ are defined as $\triangle$ ROARPE_ $\triangle R O A$ and RET-RPE_RET, respectively, where RPE_ $\triangle$ ROA and RPE_RET are as calculated in testing of $H 5$. The coefficients on both measures are expected to be negative. We also include CEO age (AGE) and age 63 dummy (AGE_63) along with CEO tenure (TENURE) as control variables to capture the well-documented age effect on turnover (Murphy and Zimmerman 1993; DeFond and Park 1999). We expect the coefficients of all three variables to be positive.

Since prior research documents that one-year analyst forecast error captures the deviation of realized earnings from expectations and provides additional information regarding a CEO's ability (Puffer and Weintrop 1991; DeFond and Park 1999; Farrell and Whidbee 2003), we calculate the adjusted analyst forecast error (FE_ADJ) as the difference between the realized EPS for the previous year and the forecasted EPS at the beginning of the previous year, scaled by the stock price at the beginning of the year. We expect FE_ADJ to be negatively associated with TURN. Stock volatility (RETVAR) has been 
shown to be positively associated with the CEO retention decision (DeFond and Park 1999; Engel, Hayes and Wang 2003). We measure stock volatility as the variance of monthly returns during the 24-month period prior to the event year. In addition, following DeFond and Park (1999), we include HerfindahlHirschman Index (HHI) as a control for industry competition. HHI is calculated as the mean of the sum of hthe squared market shares of all firms in a two-digit SIC industry over the past five years, and hence, the higher the value of HHI, the lower the industry competition, and the lower likelihood of turnover. Thus, we expect a negative coefficient on HHI. Lastly, we control for earnings volatility as suggested in Engel, Haynes and Wang (2003).

\subsubsection{Test Results of Self-Selection Model}

We present the results of probit regressions of turnover decisions in Table 10. We discuss the models with controls for self-selection. As predicted in $H 7$, the coefficient on WARN is negative (pvalue $=0.081$, supporting the hypothesis that the turnover rate is attenuated by issuing warnings. To facilitate the interpretation of the coefficients, we also compute the marginal probability effect. The result shows that ceteris paribus, the likelihood of being replaced will be reduced by 5.9 percentage points if a warning is issued in the prior year. As expected, the coefficient on AGE_63 is significantly positive. Although AGE is negatively related to turnover rate, the magnitude and significance are both much smaller than that of AGE_63. In addition, incurring an earnings loss, having a lower earnings surprise, longer tenure, and being in a more competitive industry in the previous year also lead to a higher probability of being replaced. In addition, the coefficient on the self-selection term for warning groups is significant and positive, suggesting that the factors (unobservable bad news, for example) that lead to issuance of warnings increase the probability of CEOs losing their jobs.

It is also worth mentioning that, without controlling for self-selection, the results show that the coefficient on WARN is positive $\left(\beta_{1}=0.149\right.$ with $\mathrm{p}$-value $\left.=0.011\right)$, suggesting that warnings firms tend to have a higher turnover rate. However, after controlling for self-selection, the effect becomes negative and 
marginally significant $(\mathrm{p}=0.081)$. This highlights the importance of controlling for self-selection when managers implement their discretion to decide whether or not to warn.

\section{Robustness Checks and Further Analysis}

\subsection{An Alternative Self-Selection Model Used in Fang (2005)}

Although the model by Tucker (2007) controls for self-selection, it restricts the bonus equation to carry the same coefficient $\beta$ for warning firms and non-warning firms. Ex ante, there is no reason to believe that the two types of firms should have the same compensation effect. Thus, relaxing the equality of $\beta$ makes this model more general. Fang (2005) demonstrates that by using separate second-stage models. Model specification is presented in Appendix A, Part 2 and the empirical results are shown in Table 11. Panel A of Table 11 reports the results of second-stage regression for warning and non-warning firms respectively. The results do show some pronounced differences between warnings firms and nonwarning firms. Stock returns (RET), not accounting-based returns ( $\triangle \mathrm{ROA})$, significantly affect bonus growth among warning firms, while both stock returns and accounting-based returns $(\triangle \mathrm{ROA})$ significantly affect bonus growth for non-warning firms. This difference is consistent with Hypothesis 2 that bonus sensitivity to stock returns is higher for warning firms than for non-warning firms.

Based on the regression results for warning firms and non-warning firms separately, Panel B demonstrates the warning effect for warning firms by comparing the actual change in bonus $(\Delta \ln ($ BONUS $))$ with the hypothetical change in bonus had the firm chosen not to warn. The mean of actual change is -1.117 , significantly larger in the absolute magnitude than the hypothetical change of 0.330, suggesting that if the firm had not warned, their bonus reduction would have been smaller $(\mathrm{t}-\mathrm{stat}=$ 9.26). As expected, Panel $\mathrm{C}$ shows that the actual change in bonus is significantly higher than the hypothetical value, meaning that CEO's bonus of a non-warning firm would have been reduced had the CEO issued warning (t-stat=-72.15). To summarize, the results are in line with our findings that issuing warnings has a negative effect on bonus growth. 


\subsection{Controlling for Earnings Benchmarks Used in Matsunaga \& Park (2001)}

Matsunaga and Park (2001) find evidence that CEO's bonus is negatively affected when the firm reports quarterly earnings below the analyst consensus forecasts, or below the earnings for the same quarter of the prior year, for at least two quarters during the year. If warning firms are on average more likely to miss analyst forecasts, then the result of a negative effect of warnings on CEO bonus can be driven by the fact that warning firms miss the benchmarks documented in Matsunaga and Park (2001). To control for the correlated earnings benchmarks, we test $H 1, H 2$, and $H 5$ including the twelve earningsbenchmark measures. $^{29}$

Untabulated results show that the coefficients on the six earnings-based benchmark measures are all significantly negative. This is consistent with the findings in Matsunaga and Park (2001) and indicates that a CEO' bonus is reduced if his firm misses the quarterly analyst forecasts, or miss the same quarter's earnings from last year for at least two quarters. Second, the coefficient on WARN ( $\beta_{8}=-1.813$ with pvalue $=0.000)$, RET $*$ WARN $\left(\beta_{4}=0.658\right.$ with $\mathrm{p}$-value $\left.=0.035\right)$, and RET*WARN*PEERW $\left(\beta_{6}=-0.154\right.$ with p-value $=0.062$ ) support the previous findings of $H 1, H 2$ and $H 5$ respectively. Another implication is that if a firm issues a warning and still misses analyst forecast for at least two quarters, then the compensation committee will impose double-penalty on the CEO's bonus.

\subsection{Effect of Warnings on Total Compensation}

Previous sections have shown that CEOs of warning firms are penalized on bonus, but receive more option grants. A natural follow-up question is: what is the net effect? To answer this question, we test how warnings affect total compensation, which is the sum of salary, bonus, long-term incentive payouts, restricted stocks granted, the value of stock options granted, and all other compensation in a given year. Ex ante, we do not have a predicted sign for the coefficient on WARN. We use the same specification as the model on bonuses but use total compensation as the dependent variable and find that the coefficient

\footnotetext{
${ }^{29}$ The earnings benchmarks are: whether earnings are below the consensus analyst forecast for $\mathrm{q}(\mathrm{q}=1,2,3,4)$ quarters during the fiscal year; whether earnings are below earnings for the same quarter for the previous year for $q$ quarters during the fiscal year; whether earnings are below zero for q quarters during the fiscal year.
} 
on WARN is positive but insignificant. So, it is possible that the reduced cash-based compensation is offset by the increased stock-based compensation. Nonetheless, it is worth emphasizing that the compensation structure moves towards stock-based compensation in the year warnings are issued.

\section{Concluding Remarks}

This study fills the void in the literature by empirically testing whether warnings affect CEO annual bonus, option grants, and CEO turnover. We find that warnings result in restructuring of CEO compensation. In particular, the percentage of compensation from option grants increases significantly for warnings firms than for non-warning control firms, suggesting that boards of directors adjust the compensation structure toward an incentive-oriented compensation in the year warnings are issued. In addition, firms that issue warnings have a stronger bonus-to-stock-returns sensitivity than firms that do not issue warnings after controlling for performance measures, risks, governance measures. In addition, we find evidence that compensation contracts use peer firms' stock returns and warnings to filter out the systematic shock when evaluating CEOs' performance. Lastly, we argue and show that as a benefit of issuing warnings, the likelihood of CEO turnover is reduced when warnings are issued. Taken together, it appears that by issuing warnings, managers are willing to trade off bonus cuts for more option grants and better job security. The evidence provided also helps understand how boards of directors determine and adjust compensation structure for CEOs. 
Figure 1

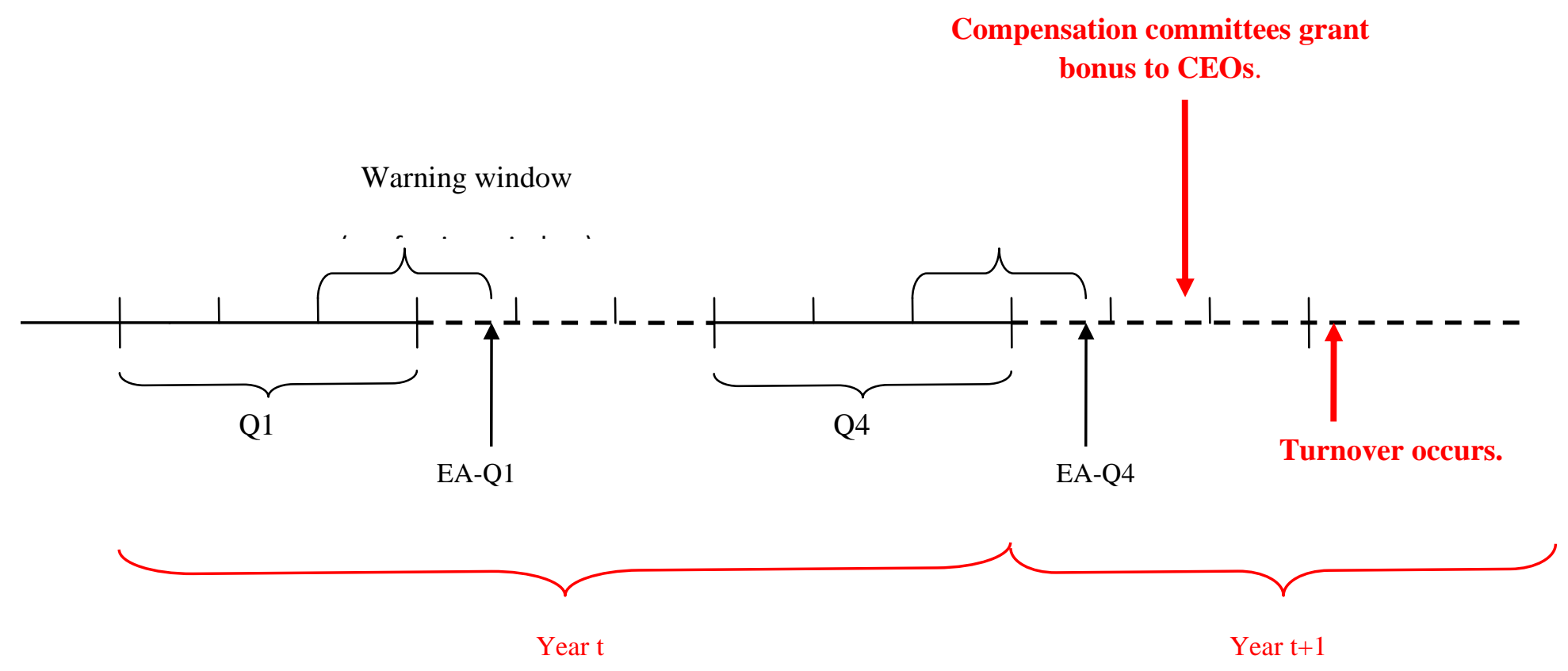




\section{Appendix A: Self-Selection Model Specifications}

\section{PART 1 Self-selection model following Tucker (2007)}

Following Tucker (2007), self-selection of to warn or not to warn is modeled in the following system:

$$
\begin{array}{ll}
\Delta \operatorname{Ln}(\text { bonus })_{1 i}=\alpha_{1}+X_{i} \beta+v_{1 i} & \left(\text { data observed only when } \operatorname{Warn}_{\mathrm{i}}^{*}>0\right) \\
\Delta \operatorname{Ln}(\text { bonus })_{0 i}=\alpha_{0}+X_{i} \beta+v_{0 i} & \left(\text { data observed only when Warn }{ }_{\mathrm{i}}^{*} \leq 0\right) \\
\operatorname{Warn}_{\mathrm{i}}^{*}=Z_{i} \gamma+\varepsilon_{i} &
\end{array}
$$

Because both the error terms in (1) and (2) may be correlated with the error term in (3), the expected value of error terms are non-zero, violating OLS assumption. To solve this problem, it is necessary to write out the conditional expectation of the error term and include it in the (1) and (2) as follows:

$$
\begin{aligned}
& E\left[\Delta \operatorname{Ln}(\text { bonus })_{1 \mathrm{i}} \mid \operatorname{warn}_{\mathrm{i}}=1\right]=\alpha_{1}+X_{i} \beta+E\left(v_{1 \mathrm{i}} \mid \varepsilon_{i}>-Z_{i} \gamma\right)=\alpha_{1}+X_{i} \beta+\sigma_{\varepsilon v_{1}} \frac{\phi\left(Z_{i} \gamma\right)}{\Phi\left(Z_{i} \gamma\right)} \\
& \left.E[\Delta \operatorname{Ln} \text { (bonus) })_{0 \mathrm{i}} \mid \operatorname{warn}_{\mathrm{i}}=0\right]=\alpha_{0}+X_{i} \beta+E\left(v_{0 \mathrm{i}} \mid \varepsilon_{i} \leq-Z_{i} \gamma\right)=\alpha_{0}+X_{i} \beta+\sigma_{\varepsilon v_{0}} \frac{-\phi\left(Z_{i} \gamma\right)}{1-\Phi\left(Z_{i} \gamma\right)}
\end{aligned}
$$

Lastly, combining (4) and (5) results in a single equation:

$$
\begin{aligned}
& \Delta \operatorname{Ln}(\text { bonus })_{\mathrm{i}}=\alpha_{0}+\theta \operatorname{Warn}_{\mathrm{i}}+X_{\mathrm{i}} \beta+\sigma_{\varepsilon v_{1}} \frac{\phi\left(Z_{i} \gamma\right)}{\Phi\left(Z_{i} \gamma\right)}+\sigma_{\varepsilon \nu_{0}} \frac{-\phi\left(Z_{i} \gamma\right)}{1-\Phi\left(Z_{i} \gamma\right)}+\omega_{\mathrm{i}} \\
& \text { where } \frac{\phi\left(Z_{i} \gamma\right)}{\Phi\left(Z_{i} \gamma\right)} \text { is denoted as IMR } * \text { Warn; } \frac{-\phi\left(Z_{i} \gamma\right)}{1-\Phi\left(Z_{i} \gamma\right)} \text { is denoted as IMR } *(1-\text { Warn })
\end{aligned}
$$




\section{PART 2 Self-selection model following Fang (2005)}

Consistent with Fang (2005), we run equation (d) and (e) respectively and compute the warning effect using the following formula:

$$
\Delta \operatorname{Ln}(\text { bonus })_{1 \mathrm{i}}-E\left[\Delta \operatorname{Ln}(\text { bonus })_{0 \mathrm{i}} \mid \operatorname{warn}_{i}^{*}>0\right]
$$

Where the second term reflects the hypothetical change in bonus for a warning firm, had the firm not warned; the first term is the actual change in bonus for a warning firm. The hypothetical value is computed as follows:

$$
E\left[\Delta \operatorname{Ln}(\text { bonus })_{0 \mathrm{i}} \mid \text { warn }_{i}^{*}>0\right]=\alpha_{0}+X_{i} \beta_{0}+\sigma_{0 \varepsilon} \frac{\phi\left(Z_{i} \gamma\right)}{\Phi\left(Z_{i} \gamma\right)}
$$

To implement equation (h), we first run equation (d) and (e) separately to obtain $\beta_{0}$ and $\beta_{1}$.

$$
\begin{aligned}
& E\left[\Delta \operatorname{Ln}(\text { bonus })_{1 \mathrm{i}} \mid \operatorname{warn}_{\mathrm{i}}=1\right]=\alpha_{1}+X_{i} \beta+E\left(v_{1 \mathrm{i}} \mid \varepsilon_{i}>-Z_{i} \gamma\right)=\alpha_{1}+X_{i} \beta_{1}+\sigma_{\varepsilon v_{1}} \frac{\phi\left(Z_{i} \gamma\right)}{\Phi\left(Z_{i} \gamma\right)} \\
& E\left[\Delta \operatorname{Ln}(\text { bonus })_{0 \mathrm{i}} \mid \operatorname{warn}_{\mathrm{i}}=0\right]=\alpha_{0}+X_{i} \beta+E\left(v_{0 \mathrm{i}} \mid \varepsilon_{i} \leq-Z_{i} \gamma\right)=\alpha_{0}+X_{i} \beta_{0}+\sigma_{\varepsilon v_{0}} \frac{-\phi\left(Z_{i} \gamma\right)}{1-\Phi\left(Z_{i} \gamma\right)}
\end{aligned}
$$

Second, to compute the hypothetical value of warning firms, we multiply the variable values, including the inverse mills ratio $\left(\frac{\phi\left(Z_{i} \gamma\right)}{\Phi\left(Z_{i} \gamma\right)}\right)$ of warning firms, by the coefficients from non-warning firms.

Third, we compute the difference between the actual change in bonus for warning firms and the computed hypothetical value of change in bonus obtained from step 2. If the difference from (g) is negative (i.e., the hypothetical change is greater than actual change in bonus), it suggests that CEO bonus of a warning firm would have not been penalized had the firm chosen not to warn, supporting the hypothesis. 


\section{Appendix B: Probit Model of Litigation Risk}

RISK on table 5 (model 2) is defined as the predicted value of litigation risk. The litigation risk model is based on the probit model used in Johnson, Kasznik, and Nelson (2001), Rogers and Stocken (2005), and Tucker (2007). The litigation data are from 1996 to 2006 and obtained from Stanford Securities Class Action Clearinghouse website. RISK is set to 1 if the firm is a defendant in a class action lawsuit filed in that year, and zero otherwise; All the explanatory variables are measured in twelve-month period previous to the event year. The model is as follows:

$$
\begin{aligned}
& \operatorname{Pr}\left(\text { RISK }_{\mathrm{it}+1}=1\right)=\Phi\left(\alpha_{0}+\alpha_{1} \mathrm{LN}_{-} \mathrm{SIZE}_{\mathrm{it}}+\alpha_{2} \text { TURNOVER }_{\mathrm{it}}+\alpha_{3} \mathrm{BETA}_{\mathrm{it}}+\alpha_{4} \mathrm{CUMRET}_{\mathrm{it}}\right. \\
& +\alpha_{5} \mathrm{STDRET}_{\mathrm{it}}+\alpha_{6} \mathrm{MINRET}_{\mathrm{it}}+\alpha_{7} \mathrm{BIO}_{\mathrm{it}}+\alpha_{8} \mathrm{COMPUTER}_{\mathrm{it}}
\end{aligned}
$$

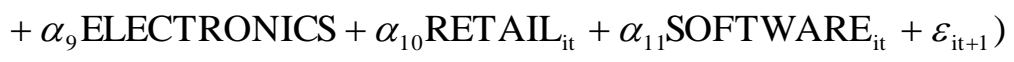

The above model was estimated using all Compustat firm years with sufficient information on CRSP during 1995 to $2005 .{ }^{30}$ To save space, the untabulated results show that all variables are significant except ELECTRONICS and RETAIL. The adjusted R-square is 0.145 comparable to the previous literature.

\footnotetext{
${ }^{30}$ For example, if a firm is sued on $2 / 1 / 1997$, then $\mathrm{RISK}=1$ in year 1997 , and all independent variables are measured during the calendar year of 1996. Then it is matched to fiscal year of 1997 for warning estimation.
} 


\section{References}

Aboody, D., and R. Kasznik. 2000. CEO stock option awards and the timing of voluntary corporate disclosures. Journal of Accounting and Economics 29: 73-100.

Aggarwal, R., and A. Samwick. 1999. The other side of the trade-off: the impact of risk on executive compensation. Journal of Political Economy 107: 65-105.

Albuquerque, A. 2009. Peer firms in relative performance evaluation. Journal of Accounting and Economics 48: 69-89.

Anilowski, C., M. Feng, and D. J. Skinner. 2007. Does earnings guidance affect market returns? The nature and information content of aggregate earnings guidance. Journal of Accounting and Economics 44 (1-2): 36-63.

Antle, R., and A. Smith. 1986. An empirical investigation of the relative performance evaluation of corporate executives. Journal of Accounting Research 24: 1-39.

Atiase, R. K., S. Supattarakul, and S. Tse. 2006. Market reaction to earnings surprise warnings: the incremental role of shareholder litigation risk on the warning effect. Journal of Accounting, Auditing and Finance (Spring): 191-222.

Baginski, S. 1987. Intraindustry information transfers associated with management forecasts of earnings. Journal of Accounting Research 25: 196-216.

Baber, W., Janakiraman, S., and S. Kang. 1996. Accounting earnings and executive compensation: The role of earnings persistence. Journal of Accounting and Economics 25: 169-193.

Bryan, S., L. Hwang, and S. Lilien. 2000. CEO stock-based compensation: an empirical analysis of incentive-intensity, relative mix, and economic determinants. Journal of Business 73: 661-693.

Cameron, A. C., and P. K. Trivedi. 2005. Microeconometrics: Methods and Applications. Cambridge University Press, New York, NY.

Carter, M. E., L. J. Lynch, and we. Tuna. 2007 The role of accounting in the design of CEO equity compensation. The Accounting Review 82: 327-357.

Chen, S., D. Mastumoto, and S. Rajgopal. 2011. Is silence golden? An empirical analysis of firms that stop giving quarterly earnings guidance. Journal of Accounting and Economics 51:134-150.

Cheng, Q., and D. Farber. 2008 Earnings restatement, changes in CEO compensation, and firm performance. The Accounting Review 83: 1217-1250.

Choi, J. H., L. Myers, Y. Zang, and D. Ziebart. 2011. Do management EPS forecasts allow returns to reflect future earnings? Implications for the continuation of management's quarterly earnings guidance. Review of Accounting Studies 16:143-182.

Coller, M., and T. Yohn. 1997. Management forecasts and information asymmetry: An examination of bid-ask spreads. Journal of Accounting Research 35: 181-191. 
Core, J., R. Holthausen, and D. Larcker. 1999. Corporate governance, chief executive officer compensation, and firm performance. Journal of Financial Economics 51: 371-406.

Core. J., and D. Larcker. 2002. Performance consequences of mandatory increases in executive stock ownership. Journal of Financial Economics 64: 317-340.

Core, J., and W. Guay. 1999. The use of equity grants to manage optimal incentive levels. Journal of Accounting and Economics 28: 151-184.

Core, J., W. Guay, and D. Larcker. 2003. Executive equity compensation and incentives: a survey. Federal Reserve Bank of New York Economic Policy Review April 2003: 27-50.

Core, J., W. Guay, and R. Verrecchia. 2003. Price versus non-price performance measures in optimal CEO compensation contracts. The Accounting Review 78: 957-981.

Cotter, J., I. Tuna, and P. Wysocki. 2006 Expectations management and beatable targets: How do analysts react to explicit earnings guidance? Contemporary Accounting Research 23: 593-624.

Darrough, M. 1995. Discussion of "Disclosure of predecision information in a duopoly". Contemporary Accounting Research 11: 861-872.

Darrough, M., and N. Stoughton. 1990. Financial disclosure policy in an entry game. Journal of Accounting and Economics 12: 219-243.

DeFond, M., and C. Park. 1999. The effect of competition on CEO turnover. Journal of Accounting and Economics 27: 35-56.

Dutta, S., and B. Trueman. 2002. The interpretation of information and corporate disclosure strategies. Review of Accounting Studies 7: 75-96.

Engel, E., R. Hayes and X. Wang. 2003. CEO turnover and properties of accounting information. Journal of Accounting and Economics 36: 197-226

Fang, L. H. 2005. Investment bank reputation and the price and quality of underwriting services. The Journal of Finance 60 (6): 2729-2761.

Farrell, K., and D. Whidbee. 2003. The impact of firm performance expectations on CEO turnover and replacement decisions. Journal of Accounting and Economics 36: 165-196.

Francis, J. R., C. S. Lennox, and Z. Wang. 2010. Selection models in accounting research. Working paper. University of Missouri-Columbia.

Garvey, G., and T. Milbourn. 2003. Incentive compensation when executives can hedge the market: evidence of relative performance evaluation in the cross section. The Journal of Finance 58: $1557-1581$.

Gibbons, R., and K. J. Murphy. 1990. Relative performance evaluation for chief executive officers. Industrial and Labor Relations Review 43: 30-51. 
Guay, W. 1999. The sensitivity of CEO wealth to equity risk: an analysis of the magnitude and determinants. Journal of Financial Economics 53: 43-71.

Han, J. C. Y., J.J. Wild, and K. Ramesh. 1989. Managers' earnings forecasts and intra-industry information transfers. Journal of Accounting and Economics 11: 3-33.

Hazarika, S., J. Karpoff, and R. Nahata. 2011. Internal corporate governance, CEO turnover, and earnings management. Working paper. Baruch College and University of Washington.

Heckman, J. J. 1979. Sample selection bias as a specification error. Econometrica 47: 153-161.

Heflin, F., K. R. Subramanyam, and Y. Zhang. 2003. Regulation FD and the financial information environment: Early evidence. The Accounting Review 78: 1-37.

Holmstrom, B. 1979. Moral hazard and observability. The Bell Journal of Economics 10: 74-91.

Holmstrom, B., and P. Milgrom. 1987. Aggregation and linearity in the provision of intertemporal incentives. Econometrica 55: 303-328.

Houston. J., B. Lev, and J. W. Tucker. 2010. To guide or not to guide? Causes and consequences of stopping quarterly earnings guidance. Contemporary Accounting Research 27: 143-185.

Hutton, A. P., G. S. Miller, and D. J. Skinner. 2003. The role of supplementary statements with management earnings forecasts. Journal of Accounting Research 41 (5): 867-890.

Janakiraman, S., R. Lambert, and D. Larcker. 1992. An empirical investigation of the relative performance evaluation hypothesis. Journal of Accounting Research 30: 53-69.

Jennings, R. 1987. Unsystematic security price movements, management earnings forecasts, and revisions in consensus analysts earnings forecasts. Journal of Accounting Research 25 (1): 90-110.

Jensen, M., and W. Mecking. 1976. Theory of the firm: Managerial behavior, agency costs and ownership structure. Journal of Financial Economics 3: 305-360.

Jensen, M., and K. Murphy. 1990. Performance pay and top-management incentives. Journal of Political Economy 98: 225-264.

Johnson, M., R. Kasznik, and K. Nelson. 2001. The impact of securities litigation reform on the disclosure of forward-looking information by high technology firms. Journal of Accounting Research 39: 297-327

Kasznik, R., and B. Lev. 1995. To warn or not to warn: Management disclosures in the face of an earnings surprise. The Accounting Review 70 (1): 113-134.

Lambert, R., and D. Larcker. 1987. An analysis of the use of accounting and market measures of performance in executive compensation contracts. Journal of Accounting Research 25: 85-125.

Larcker, D., and T. Rusticus. 2010. On the use of instrumental variables in accounting research. Journal of Accounting and Economics 49: 186-205. 
Lang, L., and R. Stulz. 1992. Contagion and competitive intra-industry effects of bankruptcy announcements. Journal of Financial Economics 32: 45-60.

Lang, M., and R. Lundholm. 1996a. Corporate disclosure policy and analyst behavior. The Accounting Review 71: 467-492.

Lang, M., and R. Lundholm. 1996b. The relation between security returns, firm earnings, and industry earnings. Contemporary Accounting Research 13: 607-629.

Lee, S., S. R. Matsunaga, and C. W. Park. 2010. Management Forecast Accuracy and CEO turnover. Working paper. University of Oregon.

Leone, A., J. Wu, and J. Zimmerman. 2006. Asymmetric sensitivity of CEO cash compensation to stock returns. Journal of Accounting and Economics 42: 167-192.

Matsumoto, D. A. 2002. Management's incentives to avoid negative earnings surprises. The Accounting Review 77 (3): 483-514.

Matsunaga, S., and C. Park. 2001. The effect of missing a quarterly earnings benchmark on the CEO's annual bonus. The Accounting Review 76 (3): 313-332.

Mercer, M. 2005. The fleeting effects of disclosure forthcomingness on management's reporting credibility. The Accounting Review 80 (2): 723-744.

Murphy, K. 1999. Executive compensation. Handbook of Labor Economics. Ashenfelter, Orley and David Card, eds. Volume 3.

Murphy, K., and J. Zimmerman. 1993. Financial performance surrounding CEO turnover. Journal of Accounting and Economics 16: 273-316.

Myers, S. 1977. Determinants of corporate borrowing. Journal of Financial Economics 5: 147-175.

Nagar, V., D. Nanda, and P. Wysocki. 2003. Discretionary disclosure and stock-based incentives. Journal of Accounting and Economics 34: 283-309.

Puffer, S., and J. Weintrop. 1991. Corporate performance and CEO turnover: the role of performance expectations. Administrative Science Quarterly 36: 1-19.

Rogers, J. L., and P.C. Stocken. 2005. Credibility of management forecasts. The Accounting Review 80 (4): 1233-1260.

Sansing, R. C. 1992. Accounting and the credibility of management forecasts. Contemporary Accounting Research 9 (1): 33-45.

Skinner, D. 1994. Why firms voluntarily disclose bad news. Journal of Accounting Research 32 (1): 3860.

Skinner, D. 1997. Earnings disclosures and stock holder lawsuits. Journal of Accounting and Economics 23 (3): 249-282. 
Sloan, R., 1993. Accounting earnings and top executive compensation. Journal of Accounting and Economics 16: 55-100.

Smith, C., and R. Watts. 1992. The investment opportunity set and corporate financing, dividend, and compensation policies. Journal of Financial Economics 32: 263-292.

Trueman, B. 1986. Why do managers voluntarily release earnings forecasts? Journal of Accounting and Economics 8: 53-71.

Trueman, B. 1997. Managerial disclosures and shareholder litigation. Review of Accounting Studies 1: 181-199.

Tse, S., and J. W. Tucker. 2010. Within-industry timing of earnings warnings: Do managers herd? Review of Accounting Studies 15: 879-914.

Tucker, J. W. 2007. Is openness penalized? Stock returns around earnings warnings. The Accounting Review 82 (4): 1055-1087. Wang, I. Y. 2007. Private earnings guidance and its implications for disclosure regulation. The Accounting Review 82: 1299-1332.

Yermack, D. 1995. Do corporations award CEO stock options effectively? Journal of Financial Economics 39: 237-269. 
Table 1: Sample Distribution and Descriptive Statatics for Testing Warning Effect

\begin{tabular}{cccccc}
\hline Panel A: Number of Observations by Year & & & & \\
\hline & Year & Warning Firms & $\begin{array}{c}\text { Non-warning } \\
\text { Control Firms }\end{array}$ & Total & $\begin{array}{c}\text { Percentage of } \\
\text { Warning firms }\end{array}$ \\
\cline { 2 - 5 } & 1996 & 59 & 546 & 605 & $10 \%$ \\
1997 & 70 & 653 & 723 & $10 \%$ \\
1998 & 128 & 612 & 740 & $17 \%$ \\
1999 & 127 & 574 & 701 & $18 \%$ \\
2000 & 140 & 527 & 667 & $21 \%$ \\
2001 & 182 & 537 & 719 & $25 \%$ \\
2002 & 142 & 429 & 571 & $25 \%$ \\
2003 & 145 & 602 & 747 & $19 \%$ \\
2004 & 120 & 609 & 729 & $16 \%$ \\
2005 & 105 & 640 & 745 & $14 \%$ \\
\hline
\end{tabular}

Panel B: Top 20 Industries with the largest Number of Warnings

\begin{tabular}{|c|c|c|c|c|c|c|}
\hline \multirow[b]{2}{*}{ Industry } & \multicolumn{2}{|c|}{ Warning Firms } & \multicolumn{2}{|c|}{ Non-Warning Firms } & \multicolumn{2}{|c|}{ Total } \\
\hline & $\#$ & $\%$ & $\#$ & $\%$ & $\#$ & $\%$ \\
\hline Chemical and Allied Products & 90 & $7.4 \%$ & 416 & $7.3 \%$ & 506 & $7.3 \%$ \\
\hline Industrial Machinery \& Equipment & 86 & $7.1 \%$ & 322 & $5.6 \%$ & 408 & $5.9 \%$ \\
\hline Electronic \& Other Electric Equipment & 81 & $6.7 \%$ & 396 & $6.9 \%$ & 477 & $6.9 \%$ \\
\hline Business Services & 63 & $5.2 \%$ & 376 & $6.6 \%$ & 439 & $6.3 \%$ \\
\hline Instruments \& Related Products & 58 & $4.8 \%$ & 253 & $4.4 \%$ & 311 & $4.5 \%$ \\
\hline Stone, Clay, \& Glass Products & 52 & $4.3 \%$ & 118 & $2.1 \%$ & 170 & $2.4 \%$ \\
\hline Food \& Kindred Products & 39 & $3.2 \%$ & 158 & $2.8 \%$ & 197 & $2.8 \%$ \\
\hline Apparel \& Accessory Stores & 39 & $3.2 \%$ & 64 & $1.1 \%$ & 103 & $1.5 \%$ \\
\hline Transportation Equipment & 38 & $3.1 \%$ & 149 & $2.6 \%$ & 187 & $2.7 \%$ \\
\hline Wholesale Trade- Durable Goods & 37 & $3.0 \%$ & 122 & $2.1 \%$ & 159 & $2.3 \%$ \\
\hline Paper \& Allied Products & 33 & $2.7 \%$ & 140 & $2.4 \%$ & 173 & $2.5 \%$ \\
\hline Printing \& Publishing & 33 & $2.7 \%$ & 102 & $1.8 \%$ & 135 & $1.9 \%$ \\
\hline Insurance Carriers & 32 & $2.6 \%$ & 230 & $4.0 \%$ & 262 & $3.8 \%$ \\
\hline Textile Mill Products & 31 & $2.5 \%$ & 40 & $0.7 \%$ & 71 & $1.0 \%$ \\
\hline Electric, Gas, \& Sanitary Services & 31 & $2.5 \%$ & 508 & $8.9 \%$ & 539 & $7.8 \%$ \\
\hline Eating \& Drinking Places & 27 & $2.2 \%$ & 104 & $1.8 \%$ & 131 & $1.9 \%$ \\
\hline Depository Institutions & 26 & $2.1 \%$ & 353 & $6.2 \%$ & 379 & $5.5 \%$ \\
\hline Fabricated Metal Products & 25 & $2.1 \%$ & 78 & $1.4 \%$ & 103 & $1.5 \%$ \\
\hline Rubber \& Miscellaneous Plastics Products & 23 & $1.9 \%$ & 48 & $0.8 \%$ & 71 & $1.0 \%$ \\
\hline Miscellaneous Retail & 23 & $1.9 \%$ & 88 & $1.5 \%$ & 111 & $1.6 \%$ \\
\hline Other & 351 & $28.8 \%$ & 1,664 & $29.0 \%$ & 2,015 & $29.0 \%$ \\
\hline Total & 1,218 & $100 \%$ & 5,729 & $100 \%$ & 6,947 & $100 \%$ \\
\hline
\end{tabular}




\begin{tabular}{|c|c|c|c|c|c|c|c|c|c|c|c|}
\hline \multicolumn{12}{|c|}{ Table 1 (continued) } \\
\hline \multicolumn{12}{|c|}{ Panel C: Descriptive Statistics } \\
\hline & \multicolumn{5}{|c|}{ FULL SAMPLE } & \multicolumn{2}{|c|}{ Warning Sample } & \multicolumn{2}{|c|}{$\begin{array}{c}\text { Non-warning } \\
\text { Control Sample }\end{array}$} & \multirow{2}{*}{\multicolumn{2}{|c|}{$\begin{array}{l}\text { Between sample } \\
\text { (Warnings-Non- } \\
\text { warnings) }\end{array}$}} \\
\hline & \multicolumn{5}{|c|}{$\mathrm{N}=6,947$} & \multicolumn{2}{|c|}{$\mathrm{N}=1,218$} & \multicolumn{2}{|c|}{$\mathrm{N}=5,729$} & & \\
\hline & Mean & Median & Q1 & Q3 & Std. Dev & Mean & Median & Mean & Median & T-stat & Z-stat \\
\hline$\Delta \ln (\mathrm{BONUS})$ & -0.169 & 0.000 & -0.393 & 0.381 & 2.755 & -1.117 & -0.229 & 0.032 & 0.026 & -13.390 & -16.452 \\
\hline$\triangle \mathrm{ROA}$ & -0.011 & -0.002 & -0.027 & 0.011 & 0.075 & -0.028 & -0.016 & -0.008 & -0.001 & -8.679 & -14.298 \\
\hline RET & 0.093 & 0.058 & -0.169 & 0.294 & 0.415 & -0.075 & -0.094 & 0.129 & 0.094 & -15.870 & -17.051 \\
\hline NEWS & 0.493 & 0.000 & 0.000 & 1.000 & 0.500 & 0.649 & 1.000 & 0.460 & 0.000 & 12.114 & 11.989 \\
\hline SUR & -0.008 & -0.003 & -0.007 & -0.001 & 0.017 & -0.012 & -0.006 & -0.007 & -0.002 & -8.481 & -21.445 \\
\hline$\triangle$ SALE & 0.085 & 0.073 & -0.003 & 0.165 & 0.209 & 0.056 & 0.052 & 0.091 & 0.077 & -5.318 & -6.338 \\
\hline LEV & 0.239 & 0.237 & 0.095 & 0.354 & 0.170 & 0.234 & 0.237 & 0.240 & 0.237 & -1.208 & -0.699 \\
\hline MB & 3.143 & 2.266 & 1.572 & 3.593 & 3.052 & 2.932 & 2.224 & 3.188 & 2.275 & -2.660 & -1.769 \\
\hline TENURE & 1.851 & 1.792 & 1.386 & 2.398 & 0.794 & 1.832 & 1.792 & 1.855 & 1.792 & -0.900 & -0.731 \\
\hline CHAIR & 0.944 & 1.000 & 1.000 & 1.000 & 0.230 & 0.933 & 1.000 & 0.947 & 1.000 & -1.920 & -1.920 \\
\hline \multicolumn{12}{|l|}{ Variable definitions: } \\
\hline BONUS & $=$ & \multirow{2}{*}{\multicolumn{10}{|c|}{$\begin{array}{l}\$ 1 \text { plus bonus from Compustat Execucomp; } \\
\text { earnings before interest, taxes, depreciation and amortization divided by the beginning-year book } \\
\text { value of total assets; }\end{array}$}} \\
\hline ROA & $=$ & & & & & & & & & & \\
\hline RET & $=$ & \multirow{2}{*}{\multicolumn{10}{|c|}{$\begin{array}{l}\text { cumulative monthly raw return from CRSP during the fiscal year; } \\
1 \text { if this year's EPS excluding extraordinary items is lower than last year's EPS excluding } \\
\text { extraordinary items, zero otherwise from Compustat; }\end{array}$}} \\
\hline NEWS & $=$ & & & & & & & & & & \\
\hline SURPRISE & $=$ & \multicolumn{10}{|c|}{$\begin{array}{l}\text { I first calculate the difference between actual EPS and the most recent consensus analyst forecast } \\
\text { a month before the fiscal quarter end date scaled by the beginning quarter share price for each } \\
\text { quarter of the year; I then take the lowest value of the scaled difference because warnings are } \\
\text { likely to occur in the quarters where the surprise is the most lowest; }\end{array}$} \\
\hline$\triangle$ SALE & $=$ & \multicolumn{10}{|c|}{ change in natural logarithm of sales from the prior year; } \\
\hline LEV & $=$ & \multicolumn{10}{|c|}{ debt divided by total assets measured at the beginning of the fiscal year; } \\
\hline MB & $=$ & \multicolumn{10}{|c|}{$\begin{array}{l}\text { market value of equity divided by the book value of common equity measured at the beginning of } \\
\text { the fiscal year; }\end{array}$} \\
\hline TENURE & $=$ & \multicolumn{10}{|c|}{$\begin{array}{l}\text { Natural logarithm of } 1 \text { plus CEO tenure which is the difference between the year the CEO } \\
\text { assumed the office and the current fiscal year; }\end{array}$} \\
\hline CHAIR & $=$ & \multicolumn{10}{|c|}{1 if the CEO is the board chair, zero otherwise. } \\
\hline
\end{tabular}


Table 2 Pearson Correlation Matrix of Variables Used in Testing Warning Effect

\begin{tabular}{|c|c|c|c|c|c|c|c|c|c|c|}
\hline$\triangle \mathrm{ROA}$ & $\begin{array}{c}\Delta \ln (\mathrm{BONUS} \\
0.217 \\
(0.000)\end{array}$ & $\triangle \mathrm{ROA}$ & RET & WARN & NEWS & JR_MIN_AI & $\triangle \mathrm{SALE}$ & $\overline{L E V}$ & MB & TENURE \\
\hline RET & $\begin{array}{c}0.237 \\
(0.000)\end{array}$ & $\begin{array}{c}0.257 \\
(0.000)\end{array}$ & & & & & & & & \\
\hline WARN & $\begin{array}{l}-0.159 \\
(0.000)\end{array}$ & $\begin{array}{l}-0.104 \\
(0.000)\end{array}$ & $\begin{array}{l}-0.187 \\
(0.000)\end{array}$ & & & & & & & \\
\hline NEWS & $\begin{array}{l}-0.242 \\
(0.000)\end{array}$ & $\begin{array}{l}-0.490 \\
(0.000)\end{array}$ & $\begin{array}{l}-0.179 \\
(0.000)\end{array}$ & $\begin{array}{c}0.144 \\
(0.000)\end{array}$ & & & & & & \\
\hline SURPRISE & $\begin{array}{c}0.084 \\
(0.000)\end{array}$ & $\begin{array}{c}0.154 \\
(0.000)\end{array}$ & $\begin{array}{c}0.181 \\
(0.000)\end{array}$ & $\begin{array}{l}-0.101 \\
(0.000)\end{array}$ & $\begin{array}{l}-0.153 \\
(0.000)\end{array}$ & & & & & \\
\hline$\triangle$ SALE & $\begin{array}{c}0.103 \\
(0.000)\end{array}$ & $\begin{array}{c}0.169 \\
(0.000)\end{array}$ & $\begin{array}{c}0.157 \\
(0.000)\end{array}$ & $\begin{array}{l}-0.064 \\
(0.000)\end{array}$ & $\begin{array}{l}-0.145 \\
(0.000)\end{array}$ & $\begin{array}{c}0.195 \\
(0.000)\end{array}$ & & & & \\
\hline LEV & $\begin{array}{c}0.026 \\
(0.034)\end{array}$ & $\begin{array}{c}0.082 \\
(0.000)\end{array}$ & $\begin{array}{l}-0.004 \\
(0.728)\end{array}$ & $\begin{array}{l}-0.015 \\
(0.227)\end{array}$ & $\begin{array}{l}-0.014 \\
(0.248)\end{array}$ & $\begin{array}{l}-0.063 \\
(0.000)\end{array}$ & $\begin{array}{c}0.010 \\
(0.408)\end{array}$ & & & \\
\hline MB & $\begin{array}{l}-0.037 \\
(0.002)\end{array}$ & $\begin{array}{l}-0.046 \\
(0.000)\end{array}$ & $\begin{array}{l}-0.078 \\
(0.000)\end{array}$ & $\begin{array}{l}-0.032 \\
(0.008)\end{array}$ & $\begin{array}{l}-0.008 \\
(0.529)\end{array}$ & $\begin{array}{c}0.130 \\
(0.000)\end{array}$ & $\begin{array}{c}0.161 \\
(0.000)\end{array}$ & $\begin{array}{l}-0.070 \\
(0.000)\end{array}$ & & \\
\hline TENURE & $\begin{array}{l}-0.039 \\
(0.001)\end{array}$ & $\begin{array}{l}-0.016 \\
(0.181)\end{array}$ & $\begin{array}{c}0.005 \\
(0.706)\end{array}$ & $\begin{array}{l}-0.011 \\
(0.368)\end{array}$ & $\begin{array}{c}0.040 \\
(0.001)\end{array}$ & $\begin{array}{c}0.011 \\
(0.355)\end{array}$ & $\begin{array}{c}0.087 \\
(0.000)\end{array}$ & $\begin{array}{l}-0.060 \\
(0.000)\end{array}$ & $\begin{array}{c}0.009 \\
(0.461)\end{array}$ & \\
\hline CHAIR & $\begin{array}{c}0.030 \\
(0.013)\end{array}$ & $\begin{array}{c}0.026 \\
(0.029)\end{array}$ & $\begin{array}{c}0.038 \\
(0.001)\end{array}$ & $\begin{array}{l}-0.023 \\
(0.055)\end{array}$ & $\begin{array}{l}-0.020 \\
(0.104)\end{array}$ & $\begin{array}{c}0.022 \\
(0.073)\end{array}$ & $\begin{array}{l}-0.006 \\
(0.636)\end{array}$ & $\begin{array}{c}0.012 \\
(0.307)\end{array}$ & $\begin{array}{l}-0.025 \\
(0.038)\end{array}$ & $\begin{array}{c}0.015 \\
(0.208)\end{array}$ \\
\hline
\end{tabular}


Table 3: Sample Distribution and Descriptive Statatics for Testing Stock-based Compensation Hypothesis

\begin{tabular}{|c|c|c|c|c|c|c|c|c|c|c|c|}
\hline \multicolumn{12}{|c|}{ Panel A: Number of Observations by Year } \\
\hline & & & \multicolumn{2}{|c|}{ Year } & \multicolumn{2}{|c|}{ Warning Firms } & \multicolumn{2}{|c|}{$\begin{array}{c}\text { Non-warning Control } \\
\text { Firms }\end{array}$} & Total & \multicolumn{2}{|c|}{$\begin{array}{l}\text { Percentage of } \\
\text { Warning firms }\end{array}$} \\
\hline & & & \multicolumn{2}{|c|}{1996} & \multicolumn{2}{|c|}{54} & \multicolumn{2}{|c|}{504} & 558 & \multicolumn{2}{|c|}{$10 \%$} \\
\hline & & & \multicolumn{2}{|c|}{1997} & \multicolumn{2}{|c|}{67} & \multicolumn{2}{|c|}{641} & 708 & \multicolumn{2}{|c|}{$9 \%$} \\
\hline & & & \multicolumn{2}{|c|}{1998} & \multicolumn{2}{|c|}{120} & \multicolumn{2}{|c|}{585} & 705 & \multicolumn{2}{|c|}{$17 \%$} \\
\hline & & & \multicolumn{2}{|c|}{1999} & \multicolumn{2}{|c|}{124} & \multicolumn{2}{|c|}{555} & 679 & \multicolumn{2}{|c|}{$18 \%$} \\
\hline & & & \multicolumn{2}{|c|}{2000} & \multicolumn{2}{|c|}{135} & \multicolumn{2}{|c|}{510} & 645 & \multicolumn{2}{|c|}{$21 \%$} \\
\hline & & & \multicolumn{2}{|c|}{2001} & \multicolumn{2}{|c|}{177} & \multicolumn{2}{|c|}{523} & 700 & & $\%$ \\
\hline & & & & & & & & 14 & 554 & & $\%$ \\
\hline & & & & & & & & 39 & 731 & & $\%$ \\
\hline & & & & & & & & & 721 & & $\%$ \\
\hline & & & & & & & & 28 & 732 & & $\%$ \\
\hline & & & & & & & & 51 & 6,733 & & $\%$ \\
\hline Panel B: Descriptive & tistics & & & & & & & & & & \\
\hline & & & L SAMP & & & Warni & Sample & $\begin{array}{r}\text { Non-warn } \\
\text { San }\end{array}$ & $\begin{array}{l}\text { ng Control } \\
\text { iple }\end{array}$ & $\begin{array}{l}\text { Betwee } \\
\text { (Warni }\end{array}$ & $\begin{array}{l}\text { sample } \\
\text { gs-Non- }\end{array}$ \\
\hline & & & $\mathrm{N}=6,733$ & & & & 182 & $\mathrm{~N}=5$ & 551 & war & ings) \\
\hline & Mean & Median & Q1 & Q3 & Std. Dev & Mean & Median & Mean & Median & T-stat & Z-stat \\
\hline$\Delta \ln (\mathrm{OPTION} \$)$ & -0.012 & 0.000 & -0.390 & 0.541 & 3.319 & -0.161 & 0.000 & 0.019 & 0.000 & -1.692 & -3.261 \\
\hline$\Delta \ln (\mathrm{OPTION} \#)$ & 0.006 & 0.000 & -0.322 & 0.525 & 2.376 & -0.095 & 0.000 & 0.028 & 0.000 & -1.617 & -1.745 \\
\hline$\Delta(\mathrm{OPTION} \%)$ & -0.154 & 0.000 & -0.446 & 0.461 & 3.477 & -0.112 & 0.000 & -0.163 & 0.000 & 0.450 & 1.838 \\
\hline$\triangle$ SHARES_OWN & -3.844 & 0.016 & -0.680 & 0.435 & 15.150 & -4.065 & 0.019 & -3.797 & 0.015 & -0.553 & 1.063 \\
\hline$\Delta$ EXER_OPT & 0.741 & 0.522 & -0.002 & 1.881 & 3.934 & 1.074 & 0.817 & 0.670 & 0.472 & 3.209 & 5.468 \\
\hline$\triangle \mathrm{SIZE}$ & 0.083 & 0.073 & -0.003 & 0.164 & 0.207 & 0.055 & 0.051 & 0.089 & 0.077 & -5.255 & -6.352 \\
\hline$\Delta \mathrm{MB}$ & -0.228 & -0.055 & -0.574 & 0.367 & 2.193 & -0.502 & -0.290 & -0.170 & -0.012 & -4.735 & -11.941 \\
\hline$\Delta \mathrm{RD}$ & 0.000 & 0.000 & 0.000 & 0.000 & 0.013 & 0.001 & 0.000 & 0.000 & 0.000 & 0.749 & 1.328 \\
\hline$\triangle \mathrm{RET}$ & -0.091 & -0.072 & -0.396 & 0.259 & 0.680 & -0.217 & -0.187 & -0.064 & -0.050 & -7.053 & -8.295 \\
\hline$\triangle \mathrm{CASH} C \mathrm{CST}$ & -0.031 & -0.008 & -0.082 & 0.050 & 0.164 & -0.018 & -0.006 & -0.034 & -0.008 & 3.089 & 1.834 \\
\hline$\triangle$ EARN_CST $^{-}$ & 0.013 & 0.000 & 0.000 & 0.000 & 0.249 & 0.029 & 0.000 & 0.010 & 0.000 & 2.369 & 2.364 \\
\hline$\Delta \mathrm{CASH}$ & -0.062 & -0.012 & -0.165 & 0.085 & 0.619 & -0.152 & -0.061 & -0.043 & -0.005 & -5.511 & -9.693 \\
\hline$\Delta \mathrm{LEV}$ & 0.005 & 0.000 & -0.024 & 0.023 & 0.070 & 0.011 & 0.000 & 0.004 & 0.000 & 3.139 & 3.079 \\
\hline$\Delta$ RISK_ID & -0.001 & -0.001 & -0.010 & 0.008 & 0.017 & 0.001 & 0.000 & -0.001 & -0.001 & 4.537 & 3.588 \\
\hline
\end{tabular}




\begin{tabular}{|c|c|c|c|c|c|c|c|c|c|c|c|c|c|}
\hline \multicolumn{14}{|c|}{$\begin{array}{l}\text { Table } 3 \text { (continued) } \\
\text { Panel C: Pearson correlation matrix of main variables }\end{array}$} \\
\hline \multirow[b]{2}{*}{$\Delta \ln ($ OPTION\#) } & \multicolumn{5}{|c|}{$\Delta \ln ($ OPTION\$ $) \Delta \ln ($ OPTION\#) $\Delta$ (OPTION\%) ,SHARES_OWI $\Delta$ EXER_OPT } & $\triangle \mathrm{SIZE}$ & $\triangle \mathrm{MB}$ & $\Delta \mathrm{RD}$ & $\triangle \mathrm{RET}$ & $\triangle \mathrm{CASH}$ CST & $\triangle \mathrm{EARN} C S T$ & $\triangle \mathrm{CASH}$ & $\Delta \mathrm{LEV}$ \\
\hline & $\begin{array}{c}0.965 \\
(0.000)\end{array}$ & & & & & & & & & & & & \\
\hline \multirow[t]{2}{*}{$\Delta(\mathrm{OPTION} \%)$} & 0.464 & 0.462 & & & & & & & & & & & \\
\hline & $(0.000)$ & $(0.000)$ & & & & & & & & & & & \\
\hline \multirow[t]{2}{*}{$\triangle$ SHARES_OWN } & -0.040 & -0.040 & -0.037 & & & & & & & & & & \\
\hline & $(0.001)$ & $(0.001)$ & $(0.002)$ & & & & & & & & & & \\
\hline \multirow[t]{2}{*}{$\triangle$ EXER_OPT } & -0.065 & -0.061 & -0.078 & 0.046 & & & & & & & & & \\
\hline & $(0.000)$ & $(0.000)$ & $(0.000)$ & $(0.000)$ & & & & & & & & & \\
\hline \multirow[t]{2}{*}{$\Delta$ SIZE } & 0.017 & 0.003 & 0.010 & -0.044 & -0.104 & & & & & & & & \\
\hline & $(0.176)$ & $(0.833)$ & $(0.409)$ & $(0.000)$ & $(0.000)$ & & & & & & & & \\
\hline \multirow[t]{2}{*}{$\Delta \mathrm{MB}$} & 0.005 & 0.000 & -0.004 & 0.022 & 0.022 & -0.036 & & & & & & & \\
\hline & $(0.657)$ & $(0.972)$ & $(0.759)$ & $(0.073)$ & $(0.071)$ & $(0.003)$ & & & & & & & \\
\hline$\Delta \mathrm{RD}$ & -0.025 & -0.020 & -0.045 & -0.003 & 0.047 & -0.059 & 0.023 & & & & & & \\
\hline \multirow[t]{2}{*}{$\triangle \mathrm{RET}$} & $\begin{array}{c}(0.045) \\
0.014\end{array}$ & 0.034 & -0.068 & 0.020 & -0.025 & -0.118 & 0.387 & -0.063 & & & & & \\
\hline & $(0.264)$ & $(0.006)$ & $(0.000)$ & $(0.102)$ & $(0.037)$ & $(0.000)$ & $(0.000)$ & $(0.000)$ & & & & & \\
\hline$\Delta$ CASH_CST & -0.016 & -0.022 & 0.019 & 0.005 & -0.010 & 0.005 & -0.007 & 0.038 & -0.037 & & & & \\
\hline \multirow{2}{*}{$\Delta$ EARN_CST } & $\begin{array}{l}(0.203) \\
-0.029\end{array}$ & $(0.069)$ & $\begin{array}{c}(0.129) \\
0.025\end{array}$ & $(0.658)$ & $(0.427)$ & $(0.688)$ & $(0.570)$ & $(0.002)$ & $\begin{array}{l}(0.002) \\
-0.033\end{array}$ & & & & \\
\hline & $\begin{array}{l}-0.029 \\
(0.019)\end{array}$ & $\begin{array}{l}-0.007 \\
(0.553)\end{array}$ & $\begin{array}{c}0.025 \\
(0.038)\end{array}$ & $\begin{array}{l}-0.019 \\
(0.125)\end{array}$ & $\begin{array}{c}0.010 \\
(0.414)\end{array}$ & $\begin{array}{l}-0.180 \\
(0.000)\end{array}$ & $\begin{array}{c}0.002 \\
(0.865)\end{array}$ & $\begin{array}{c}0.104 \\
(0.000)\end{array}$ & $\begin{array}{l}-0.033 \\
(0.006)\end{array}$ & $\begin{array}{l}0.099 \\
(0.000)\end{array}$ & & & \\
\hline \multirow[t]{2}{*}{$\triangle \mathrm{CASH}$} & 0.006 & 0.017 & -0.146 & 0.008 & 0.040 & -0.349 & 0.089 & -0.019 & 0.215 & 0.023 & -0.007 & & \\
\hline & $(0.650)$ & $(0.156)$ & $(0.000)$ & $(0.528)$ & $(0.001)$ & $(0.000)$ & $(0.000)$ & $(0.122)$ & $(0.000)$ & $(0.056)$ & $(0.547)$ & & \\
\hline \multirow[t]{2}{*}{$\Delta \mathrm{LEV}$} & -0.025 & -0.016 & 0.000 & 0.019 & 0.040 & 0.006 & 0.064 & 0.013 & -0.015 & -0.086 & 0.053 & -0.068 & \\
\hline & $(0.044)$ & $(0.196)$ & $(0.991)$ & $(0.124)$ & $(0.001)$ & $(0.627)$ & $(0.000)$ & $(0.290)$ & $(0.211)$ & $(0.000)$ & $(0.000)$ & $(0.000)$ & \\
\hline \multirow[t]{2}{*}{$\Delta$ RISK_ID } & 0.018 & 0.041 & 0.046 & 0.002 & -0.017 & 0.053 & -0.101 & -0.003 & -0.095 & 0.046 & 0.092 & -0.068 & 0.030 \\
\hline & $(0.138)$ & $(0.001)$ & $(0.000)$ & $(0.858)$ & $(0.162)$ & $(0.000)$ & $(0.000)$ & $(0.796)$ & $(0.000)$ & $(0.000)$ & $(0.000)$ & $(0.000)$ & $(0.016)$ \\
\hline \multicolumn{14}{|l|}{ Variable Definitions: } \\
\hline \multicolumn{14}{|l|}{$\begin{array}{r}\text { Varlable Definitions: } \\
\ln (\text { OPTION\$) }\end{array}$} \\
\hline \multicolumn{14}{|c|}{$\begin{array}{l}\ln (\text { OPTION\$ })=\text { natural logarithm of } 1 \text { plus the Black-Scholes value of annual option } \\
\ln (\text { OPTION\# })=\text { natural logarithm of } 1 \text { plus the number of the annual option grants; }\end{array}$} \\
\hline \multirow{2}{*}{ OPTION\% } & $=$ Black-Scholes & e of annual & n-based con & sation divide & y annual total & npesnation & & & & & & & \\
\hline & $=$ CEO's owners & shares (op & excluded) $\mathrm{d}$ & ed by number & outstanding $\mathrm{s}$ & & & & & & & & \\
\hline $\begin{array}{r}\text { SHARES_OWN } \\
\text { EXER OPT }\end{array}$ & $=$ CEO's exercis & $\begin{array}{l}\text { options in } \mathrm{s} \text {. } \\
\text { ons }\end{array}$ & s divided by 1 & ber of outstar & g shares; & & & & & & & & \\
\hline $\begin{array}{r}\text { EXER_OPT } \\
\text { SIZE }\end{array}$ & $=$ natural logaritl & sales; & & & & & & & & & & & \\
\hline $\mathrm{MB}$ & $=$ market value $\mathrm{c}$ & ets divided & ook value; & & & & & & & & & & \\
\hline & $=$ resaerch and $\mathrm{c}$ & opment exp & & & & & & & & & & & \\
\hline RET & $=$ acccumulated & onth stock & & & & & & & & & & & \\
\hline CASH_CST & $=$ common and $\mathrm{p}$ & red dividen & inus net cash & w from inves & ent activities $n$ & is net cash & from oper & activities, tl & vided by to & assets; & & & \\
\hline EARN_CST & $=1$ if there is an & ating earnin & $\mathrm{ss} ; 0$ otherw & & & & & & & & & & \\
\hline $\mathrm{CASH}$ & $=$ sum of annual & $y$ and bonu & ided by sales & & & & & & & & & & \\
\hline LEV & $=$ long-term asse & vided by tot & sets; & & & & & & & & & & \\
\hline SK_ID & $=$ standard devia & of the residt & m the mark & nodel using $\mathrm{w}$ & kly reuturns & 11 & & & & & & & \\
\hline
\end{tabular}


Table 4: Sample Distribution and Descriptive Statatics for Testing Turnover Hypothesis

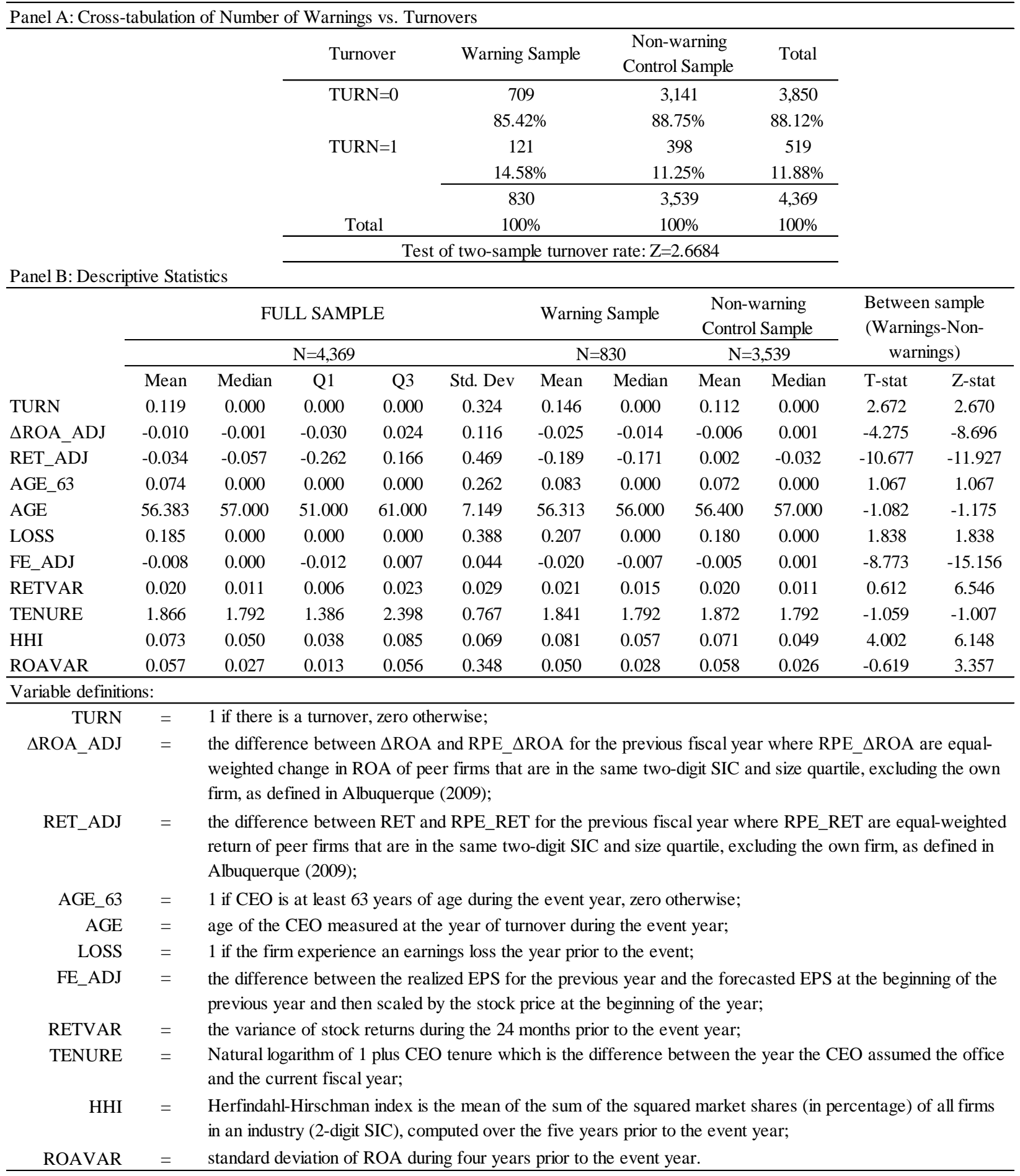


Table 5: First Stage Probit Analysis of the Choice to Issue Warnings

$$
\begin{aligned}
\operatorname{Pr}\left(\text { WARN }_{\mathrm{it}}=1\right) & =\Phi\left(\alpha_{0}+\alpha_{1} \mathrm{RISK}_{\mathrm{it}}+\alpha_{2} \mathrm{LN}_{-} \mathrm{MVE}\right. \\
& +\alpha_{4} \mathrm{PAST}_{\mathrm{it}}+\alpha_{3} \mathrm{UPIDE}_{\mathrm{t}}+\alpha_{5} \mathrm{NUMEST}_{\mathrm{it}}+\alpha_{6} \mathrm{IOR}_{\mathrm{it}}+\alpha_{7} \mathrm{NEWS}_{\mathrm{it}} \\
& \left.+\alpha_{8} \mathrm{SURPRISE}+\alpha_{9} \mathrm{MB}_{\mathrm{it}}+\alpha_{10} \mathrm{ROA}_{-} \mathrm{STD}_{\mathrm{it}}+\alpha_{11} \mathrm{FD}_{\mathrm{it}}+\varepsilon_{\mathrm{it}}\right)
\end{aligned}
$$

\begin{tabular}{|c|c|c|c|c|}
\hline Independent Variables ${ }^{1}$ & $\begin{array}{l}\text { Predicted } \\
\text { Sign }\end{array}$ & Coefficient & $\begin{array}{c}\text { Robust Std } \\
\text { Err }^{2}\end{array}$ & P-value 3 \\
\hline Intercept & & -0.803 & 0.156 & 0.000 \\
\hline RISK & + & 3.336 & 0.664 & 0.000 \\
\hline LN_MVE & + & -0.163 & 0.021 & 0.000 \\
\hline UPDATE_GUIDE & + & 0.551 & 0.047 & 0.000 \\
\hline PAST_GUIDE & + & 0.030 & 0.006 & 0.000 \\
\hline NUMEST & + & 0.008 & 0.004 & 0.031 \\
\hline IOR & + & 0.609 & 0.106 & 0.000 \\
\hline NEWS & + & 0.406 & 0.038 & 0.000 \\
\hline SURPIRSE & - & -6.591 & 0.994 & 0.000 \\
\hline MB & + & -0.011 & 0.007 & 0.051 \\
\hline ROA_STD & - & -1.529 & 0.351 & 0.000 \\
\hline FD & & -0.062 & 0.042 & 0.145 \\
\hline Pseudo $\mathrm{R}^{2}$ & \multicolumn{4}{|c|}{0.101} \\
\hline Number of obs & \multicolumn{4}{|c|}{6,947} \\
\hline
\end{tabular}

${ }^{1}$ Variable definitions:

WARN $=1$ if a firm issues an earnings warning after the beginning of the third fiscal month and before the quarterly earnings announcement date in any quarter of the fiscal year, zero otherwise;

RISK = predicted value of the likelihood of being sued (see appendix B);

LN_MVE = natural logarithm of market value of equity measured at the beginning of the fiscal year;

SURPIRSE = I first calculate the difference between actual EPS and the most recent consensus analyst forecast a month before the fiscal quarter end date scaled by the beginning quarter share price for each quarter of the year; I then take the lowest value of the scaled difference because warnings are likely to occur in the quarters where the surprise is most lowest;

UPDATE_GUIDE $=1$ if a firm has issued earning forecast before the third fiscal month of any fiscal quarter, zero otherwise;

PAST_GUIDE = number of earnings guidance issued by a firm in the previous fiscal year;

NUMEST = average number of analysts whose earnings forecasts are included in the most recent consensus compiled before the third month of the fiscal quarters during the fiscal year;

IOR = number of institutional holdings divided by total number of shares outstanding measured at the beginning of the fiscal year;

NEWS $=1$ if this year's EPS excluding extraordinary items is lower than last year's EPS excluding extraordinary items, zero otherwise from Compustat;

$\mathrm{MB}$ = market value of equity divided by the book value of common equity measured at the beginning of the fiscal year;

ROA_STD = standard deviation of ROA during the past four fiscal years;

FD $=1$ if fiscal year-end date is after 01/10/ 2000 the date the Regulation Fair Disclosure takes effect.

2:The standard errors are adjusted for heteroscedasticity and clustered by firm.

3:P-values are based on one-tailed for variables with predicted signs and two-tailed for variables without predicted signs. 
Table 6: Testing the Relation between Change in CEO bonus and Warnings

\begin{tabular}{|c|c|c|c|c|c|c|c|c|c|c|}
\hline \multirow[b]{4}{*}{ Independent Variables ${ }^{1}$} & \multicolumn{10}{|c|}{$\begin{aligned} \Delta \ln \left(\mathrm{BONUS}_{\mathrm{it}}\right) & =\beta_{0}+\beta_{1} \Delta \mathrm{ROA}_{\mathrm{it}}+\beta_{2} \mathrm{RET}_{\mathrm{it}}+\beta_{3} \Delta \mathrm{ROA}_{\mathrm{it}} \times \mathrm{WARN}_{\mathrm{it}}+\beta_{4} \Delta \mathrm{RET}_{\mathrm{it}} \times \mathrm{WARN}_{\mathrm{it}} \\
& +\beta_{5} \mathrm{WARN}_{\mathrm{it}}+\beta_{6} \mathrm{NEWS}_{\mathrm{it}}+\beta_{7} \mathrm{SURPRISE}_{\mathrm{it}}+\beta_{8} \Delta \mathrm{SALE}_{\mathrm{it}}+\beta_{9} \mathrm{LEV}_{\mathrm{it}} \\
& +\beta_{10} \mathrm{MB}_{\mathrm{it}}+\beta_{11} \mathrm{TENURE}_{\mathrm{it}}+\beta_{12} \mathrm{CHAIR}_{\mathrm{it}}+\beta_{13} \mathrm{IMR}_{\mathrm{it}} * \mathrm{WARN}_{\mathrm{it}} \\
& +\beta_{14} \mathrm{MR}_{\mathrm{it}} *\left(1-\mathrm{WARN}_{\mathrm{it}}\right)+\varepsilon_{\mathrm{it}}\end{aligned}$} \\
\hline & \multirow{3}{*}{$\begin{array}{l}\text { Predicted } \\
\text { Sign }\end{array}$} & \multicolumn{3}{|c|}{ no control for self-selection } & \multicolumn{3}{|c|}{ control for self-selection } & \multicolumn{3}{|c|}{ control for self-selection } \\
\hline & & \multicolumn{3}{|c|}{ Robust Std. } & \multicolumn{3}{|c|}{ Robust Std. } & \multicolumn{3}{|c|}{ Robust } \\
\hline & & Coef. & $\operatorname{Err}^{2}$ & $\mathrm{P}$-value ${ }^{3}$ & Coef. & $\mathrm{Err}^{2}$ & P-value ${ }^{3}$ & Coef. & Std. Err ${ }^{2}$ & P-value ${ }^{3}$ \\
\hline Intercept & & 0.248 & 0.166 & 0.134 & 0.232 & 0.173 & 0.180 & 0.296 & 0.174 & 0.089 \\
\hline$\Delta \mathrm{ROA}$ & + & 2.588 & 0.567 & 0.000 & 2.700 & 0.568 & 0.000 & 2.624 & 0.569 & 0.000 \\
\hline RET & + & 1.164 & 0.094 & 0.000 & 1.166 & 0.095 & 0.000 & 1.235 & 0.102 & 0.000 \\
\hline$\triangle \mathrm{ROA}^{*} \mathrm{WARN}$ & & 0.100 & 1.409 & 0.943 & -0.891 & 1.448 & 0.539 & 0.038 & 1.911 & 0.984 \\
\hline RET*WARN & + & 0.372 & 0.280 & 0.093 & 0.334 & 0.278 & 0.115 & 0.778 & 0.359 & 0.015 \\
\hline$\triangle \mathrm{ROA}^{*} \mathrm{WARN} * \mathrm{PEERW}$ & & & & & & & & -0.192 & 0.353 & 0.585 \\
\hline RET*WARN*PEERW & & & & & & & & -0.173 & 0.099 & 0.040 \\
\hline WARN & & -0.685 & 0.097 & 0.000 & -1.845 & 0.394 & 0.000 & -1.773 & 0.407 & 0.000 \\
\hline PEERW & & & & & & & & 0.012 & 0.038 & 0.745 \\
\hline RPE_ $\triangle \mathrm{ROA}$ & & & & & & & & 2.440 & 1.021 & 0.017 \\
\hline RPE_RET & & & & & & & & -0.368 & 0.145 & 0.006 \\
\hline NEWS & - & -0.798 & 0.076 & 0.000 & -0.743 & 0.081 & 0.000 & -0.740 & 0.082 & 0.000 \\
\hline SURPRISE & + & 0.046 & 2.313 & 0.492 & -0.717 & 2.365 & 0.381 & -0.805 & 2.345 & 0.366 \\
\hline$\triangle \mathrm{SALE}$ & + & 0.729 & 0.175 & 0.000 & 0.737 & 0.176 & 0.000 & 0.720 & 0.174 & 0.000 \\
\hline LEV & & 0.294 & 0.179 & 0.101 & 0.304 & 0.179 & 0.090 & 0.304 & 0.179 & 0.091 \\
\hline MB & & -0.027 & 0.010 & 0.006 & -0.029 & 0.010 & 0.003 & -0.029 & 0.010 & 0.004 \\
\hline TENURE & - & -0.135 & 0.035 & 0.000 & -0.134 & 0.035 & 0.000 & -0.132 & 0.035 & 0.000 \\
\hline CHAIR & + & 0.182 & 0.113 & 0.054 & 0.175 & 0.113 & 0.061 & 0.183 & 0.113 & 0.053 \\
\hline IMR*WARN & & & & & 0.814 & 0.260 & 0.002 & 0.750 & 0.261 & 0.004 \\
\hline IMR $*(1-W A R N)$ & & & & & 0.117 & 0.259 & 0.652 & 0.081 & 0.259 & 0.754 \\
\hline Year dummy & & & yes & & & yes & & & yes & \\
\hline Industry dummy & & & yes & & & yes & & & yes & \\
\hline $\operatorname{adj} \_R^{2}$ & & & 0.121 & & & 0.122 & & & 0.125 & \\
\hline Number of obs & & & 6,947 & & & 6,947 & & & 6,947 & \\
\hline
\end{tabular}


${ }^{1}$ Variable definitions (All other variables are defined in Table 1):

WARN = 1 if a firm issues an earnings warning after the beginning of the third fiscal month and before the quarterly earnings announcement date in any quarter of the fiscal year, zero otherwise;

PEERW = number of peers firms that issued warning during the year. see section 4.3 "four steps taken to define PEERW and PEERT";

RPE_ $\triangle \mathrm{ROA}=$ equal-weighted change in ROA of peer firms that are in the same two-digit SIC and size quartile, excluding the own firm, as defined in Albuquerque (2009);

RPE_RET = equal-weighted return of peer firms that are in the same two-digit SIC and size quartile, excluding the own firm, as defined in Albuquerque (2009);

$\mathrm{IMR}=$ see model specification in Appendix A, part 1.

2:The standard errors are adjusted for heteroscedasticity and clustered by firm.

3:P-values are based on one-tailed for variables with predicted signs and two-tailed for variables without predicted signs. 
Table 7: Testing the Relation between Change in CEO Option Grants and Warnings after Controlling for Self-Selection

$$
\begin{aligned}
\Delta\left(\mathrm{OPTION}_{\mathrm{it}}\right)= & \beta_{0}+\beta_{1} \mathrm{WARN}_{\mathrm{it}}+\beta_{2} \Delta \mathrm{RET}_{\mathrm{it}} \times \mathrm{WARN}_{\mathrm{it}}+\beta_{3} \Delta \mathrm{SHARES}_{-} \mathrm{OWN} \mathrm{it}_{\mathrm{it}}+\beta_{4} \Delta \mathrm{EXER}_{2} \mathrm{OPT}_{\mathrm{it}} \\
& +\beta_{5} \Delta \mathrm{SIZE}_{\mathrm{it}}+\beta_{6} \Delta \mathrm{MB}_{\mathrm{it}}+\beta_{7} \Delta \mathrm{RD}_{\mathrm{it}}+\beta_{8} \Delta \mathrm{RET}_{\mathrm{it}}+\beta_{9} \Delta \mathrm{CASH} \mathrm{CST}_{\mathrm{it}} \\
& +\beta_{10} \Delta \mathrm{EARN}_{\mathrm{CSST}}+\beta_{11} \Delta \mathrm{CASH}_{\mathrm{it}}+\beta_{12} \Delta \mathrm{LEV}_{\mathrm{it}}+\beta_{13} \Delta \mathrm{RISK}_{\mathrm{II}} \mathrm{ID}_{\mathrm{it}}+\beta_{14} \mathrm{IMR}_{\mathrm{it}} * \mathrm{WARN}_{\mathrm{it}} \\
& +\beta_{15} \mathrm{IMR}_{\mathrm{it}} *\left(1-\mathrm{WARN}_{\mathrm{it}}\right)+\varepsilon_{\mathrm{it}}
\end{aligned}
$$

\begin{tabular}{|c|c|c|c|c|c|c|c|c|c|c|}
\hline \multirow{3}{*}{$\begin{array}{c}\text { Dependent Variables } \\
\text { Independent Variables }{ }^{1}\end{array}$} & \multirow{3}{*}{$\begin{array}{l}\text { Predicted } \\
\text { Sign }\end{array}$} & \multicolumn{3}{|c|}{$\Delta \ln (\mathrm{OPTION} \$)$} & \multicolumn{3}{|c|}{$\Delta \ln ($ OPTION\# $)$} & \multicolumn{3}{|c|}{$\triangle \mathrm{OPTION} \%$} \\
\hline & & & Robust & & & Robust & & & Robust & \\
\hline & & Coef. & Std. Err ${ }^{2}$ & P-value ${ }^{3}$ & Coef. & Std. Err ${ }^{2}$ & P-value ${ }^{3}$ & Coef. & Std. Err ${ }^{2}$ & P-value ${ }^{3}$ \\
\hline Intercept & & 0.278 & 0.150 & 0.063 & 0.144 & 0.107 & 0.177 & 0.175 & 0.127 & 0.169 \\
\hline WARN & + & 0.577 & 0.359 & 0.054 & 0.615 & 0.259 & 0.009 & 1.180 & 0.437 & 0.004 \\
\hline$\triangle \mathrm{RET} * \mathrm{WARN}$ & + & -0.139 & 0.168 & 0.204 & -0.048 & 0.124 & 0.348 & -0.261 & 0.203 & 0.100 \\
\hline$\triangle$ SHARES_OWN & - & -0.008 & 0.003 & 0.003 & -0.005 & 0.002 & 0.002 & -0.008 & 0.003 & 0.006 \\
\hline$\triangle E X E R \_O P T$ & - & -0.051 & 0.014 & 0.000 & -0.035 & 0.010 & 0.000 & -0.065 & 0.016 & 0.000 \\
\hline$\triangle \mathrm{SIZE}$ & + & 0.009 & 0.243 & 0.485 & -0.028 & 0.177 & 0.438 & -1.095 & 0.321 & 0.001 \\
\hline$\Delta \mathrm{MB}$ & + & 0.006 & 0.025 & 0.410 & -0.009 & 0.019 & 0.311 & 0.052 & 0.031 & 0.048 \\
\hline$\Delta \mathrm{RD}$ & & -3.796 & 2.910 & 0.192 & -2.009 & 2.230 & 0.368 & -14.307 & 4.711 & 0.002 \\
\hline$\triangle \mathrm{RET}$ & + & 0.120 & 0.090 & 0.092 & 0.157 & 0.067 & 0.010 & -0.197 & 0.110 & 0.037 \\
\hline$\triangle \mathrm{CASH} C \mathrm{CST}$ & + & -0.143 & 0.265 & 0.295 & -0.226 & 0.194 & 0.122 & 0.378 & 0.291 & 0.098 \\
\hline$\triangle E A R N \_C S T$ & & -0.370 & 0.195 & 0.058 & -0.117 & 0.147 & 0.425 & 0.151 & 0.238 & 0.527 \\
\hline$\Delta \mathrm{CASH}$ & & 0.030 & 0.093 & 0.747 & 0.058 & 0.065 & 0.379 & -0.860 & 0.117 & 0.000 \\
\hline$\triangle \mathrm{LEV}$ & - & -1.140 & 0.689 & 0.049 & -0.488 & 0.501 & 0.165 & -0.980 & 0.725 & 0.089 \\
\hline$\Delta$ RISK_ID & + & -1.924 & 3.088 & 0.267 & 1.901 & 2.264 & 0.201 & 4.596 & 3.731 & 0.109 \\
\hline IMR*W ARN & & -0.504 & 0.257 & 0.05 & -0.461 & 0.186 & 0.013 & -0.935 & 0.317 & 0.003 \\
\hline IMR*(1-WARN) & & -0.128 & 0.281 & 0.648 & -0.314 & 0.198 & 0.113 & -0.179 & 0.303 & 0.555 \\
\hline Year dummy & & & yes & & & yes & & & yes & \\
\hline Industry dummy & & & yes & & & yes & & & yes & \\
\hline $\operatorname{adj} \_R^{2}$ & & & 0.015 & & & 0.017 & & & 0.045 & \\
\hline Number of obs & & & 6,733 & & & 6,733 & & & 6,733 & \\
\hline
\end{tabular}

6,733

2:The standard errors are adjusted for heteroscedasticity and clustered by firm.

3:P-values are based on one-tailed for variables with predicted signs and two-tailed for variables without predicted signs. 
Table 8: Analysis of Change in CEO Option Grants and Peer Firms' Warnings

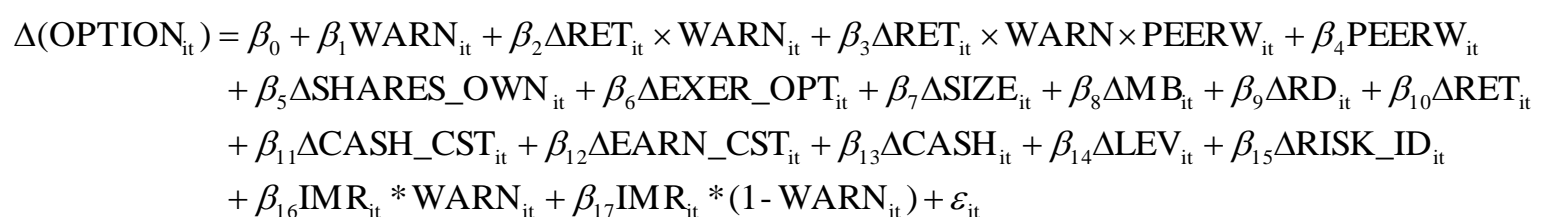

\begin{tabular}{|c|c|c|c|c|c|c|c|c|c|c|}
\hline \multirow{3}{*}{$\begin{array}{l}\text { Dependent Variables } \\
\text { Independent Variables }{ }^{1}\end{array}$} & \multirow{3}{*}{$\begin{array}{c}\text { Predicted } \\
\text { Sign }\end{array}$} & \multicolumn{3}{|c|}{$\Delta \ln (\mathrm{OPTION} \$)$} & \multicolumn{3}{|c|}{$\Delta \ln (\mathrm{OPTION} \#)$} & \multicolumn{3}{|c|}{$\triangle \mathrm{OPTION} \%$} \\
\hline & & & Robust & & & Robust & & & Robust & \\
\hline & & Coef. & Std. Err ${ }^{2}$ & P-value ${ }^{3}$ & Coef. & Std. Err' ${ }^{2}$ & P-value ${ }^{3}$ & Coef. & Std. Err' ${ }^{2}$ & P-value ${ }^{3}$ \\
\hline Intercept & & 0.278 & 0.150 & 1.860 & 0.144 & 0.107 & 1.350 & 0.175 & 0.127 & 1.380 \\
\hline WARN & + & 0.637 & 0.372 & 0.044 & 0.649 & 0.267 & 0.008 & 1.318 & 0.441 & 0.002 \\
\hline$\triangle \mathrm{RET}^{*} \mathrm{WARN}$ & + & 0.128 & 0.200 & 0.261 & 0.147 & 0.148 & 0.160 & 0.338 & 0.245 & 0.084 \\
\hline$\triangle \mathrm{RET}^{*}$ WARN*PEERW & - & -0.095 & 0.038 & 0.006 & -0.069 & 0.027 & 0.006 & -0.214 & 0.054 & 0.000 \\
\hline PEERW & & -0.027 & 0.036 & 0.449 & -0.016 & 0.025 & 0.527 & -0.061 & 0.039 & 0.114 \\
\hline$\triangle$ SHARES_OWN & - & -0.008 & 0.003 & 0.002 & -0.006 & 0.002 & 0.002 & -0.008 & 0.003 & 0.005 \\
\hline$\triangle$ EXER_OPT & - & -0.050 & 0.014 & 0.000 & -0.035 & 0.010 & 0.000 & -0.064 & 0.016 & 0.000 \\
\hline$\triangle \mathrm{SIZE}$ & + & 0.008 & 0.244 & 0.487 & -0.028 & 0.178 & 0.438 & -1.098 & 0.321 & 0.001 \\
\hline$\triangle \mathrm{MB}$ & + & 0.007 & 0.025 & 0.393 & -0.009 & 0.019 & 0.327 & 0.055 & 0.031 & 0.040 \\
\hline$\Delta \mathrm{RD}$ & & -3.977 & 2.908 & 0.172 & -2.141 & 2.227 & 0.336 & -14.711 & 4.705 & 0.002 \\
\hline$\triangle \mathrm{RET}$ & + & 0.120 & 0.090 & 0.093 & 0.156 & 0.067 & 0.010 & -0.199 & 0.110 & 0.036 \\
\hline$\triangle \mathrm{CASH} C \mathrm{CST}$ & + & -0.152 & 0.265 & 0.284 & -0.233 & 0.193 & 0.115 & 0.359 & 0.291 & 0.108 \\
\hline$\triangle \mathrm{EARN} C \mathrm{CST}$ & & -0.368 & 0.195 & 0.060 & -0.115 & 0.147 & 0.433 & 0.155 & 0.240 & 0.518 \\
\hline$\triangle \mathrm{CASH}$ & & 0.029 & 0.093 & 0.753 & 0.057 & 0.065 & 0.382 & -0.862 & 0.118 & 0.000 \\
\hline$\triangle \mathrm{LEV}$ & - & -1.094 & 0.690 & 0.057 & -0.454 & 0.501 & 0.183 & -0.875 & 0.732 & 0.116 \\
\hline$\Delta$ RISK_ID & + & -1.908 & 3.084 & 0.268 & 1.912 & 2.261 & 0.199 & 4.633 & 3.727 & 0.107 \\
\hline IMR*WARN & & -0.508 & 0.257 & 0.048 & -0.463 & 0.186 & 0.013 & -0.945 & 0.311 & 0.002 \\
\hline $\mathrm{IMR}^{*}(1-\mathrm{WARN})$ & & -0.129 & 0.281 & 0.648 & -0.314 & 0.198 & 0.113 & -0.180 & 0.303 & 0.553 \\
\hline Year dummy & & & yes & & & yes & & & yes & \\
\hline Industry dummy & & & yes & & & yes & & & yes & \\
\hline $\operatorname{adj} \_R^{2}$ & & & 0.016 & & & 0.017 & & & 0.048 & \\
\hline Number of obs & & & 6,733 & & & 6,733 & & & 6,733 & \\
\hline
\end{tabular}

1Variable definitions:

PEERW = number of peers firms that issued warning during the year. see section 4.3 "four steps taken to define PEERW";

All other variables are as defined in Table 3 and IMR are obtained from first-stage self-selection model (2) in Table 5. 
Table 9: Validation of the Litigation Risk Related and Analyst Forecast Related Incentives of Issuing Warnings $\underline{\text { Panel A: Comparison of predicted litigation risk between warning firms and non-warning firms }}$

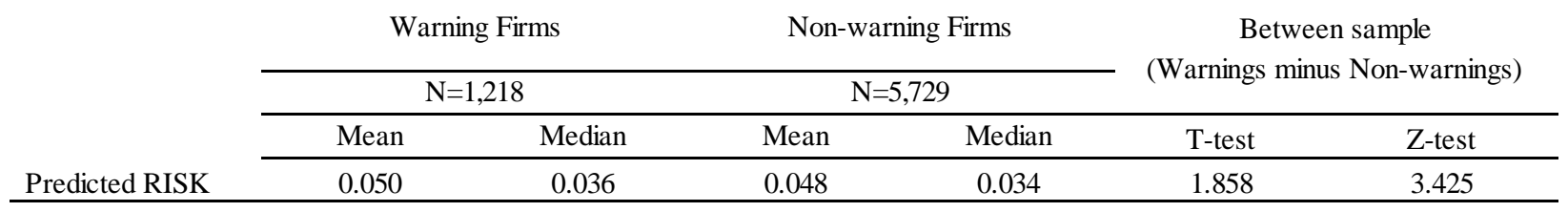

Panel B: Comparison of earnings surprise before and after confession window

\begin{tabular}{|c|c|c|c|c|c|c|}
\hline & \multicolumn{3}{|c|}{ Warning Quarters ${ }^{1}$} & \multicolumn{3}{|c|}{ Non-Warning Quarters ${ }^{2}$} \\
\hline & \multicolumn{3}{|c|}{$\mathrm{N}=1,486$} & \multicolumn{3}{|c|}{$\mathrm{N}=10,641$} \\
\hline & Before Warnings & After Warnings & $\begin{array}{l}\text { Matched Pair T- } \\
\text { test (After minus }\end{array}$ & $\begin{array}{c}\text { Before } \\
\text { Confession } \\
\text { Window }\end{array}$ & $\begin{array}{c}\text { After } \\
\text { Confession } \\
\text { Window }\end{array}$ & $\begin{array}{c}\text { Matched Pair T- } \\
\text { test (After minus } \\
\text { Before) }\end{array}$ \\
\hline & Mean & Mean & & Mean & Mean & \\
\hline AFE & -0.812 & -0.508 & 2.215 & -0.163 & -0.098 & 5.071 \\
\hline ABS(AFE) & 0.815 & 0.527 & -2.098 & 0.163 & 0.111 & -4.079 \\
\hline MEET & 0.037 & 0.483 & 22.708 & 0 & 0.278 & 63.944 \\
\hline
\end{tabular}

Panel C: Comparison of change in earnings surprise between warning sample and non-warning sample

\begin{tabular}{|c|c|c|c|c|c|c|}
\hline & \multicolumn{2}{|c|}{ Warning Quarters } & \multicolumn{2}{|c|}{ Non-warning Quarters } & \multirow{2}{*}{\multicolumn{2}{|c|}{$\begin{array}{c}\text { Between sample } \\
\text { (Warning minus Non-warning) }\end{array}$}} \\
\hline & \multicolumn{2}{|c|}{$\mathrm{N}=1,486$} & \multicolumn{2}{|c|}{$\mathrm{N}=10,641$} & & \\
\hline & Mean & Median & Mean & Median & T-test & Z-test \\
\hline$\triangle \mathrm{AFE}^{3}$ & 0.304 & 0.06 & 0.065 & 0.01 & 3.861 & 28.288 \\
\hline$\triangle \mathrm{ABS}(\mathrm{AFE})$ & -0.288 & -0.05 & -0.052 & -0.01 & 3.824 & 28.201 \\
\hline$\triangle \mathrm{MEET}$ & 0.446 & 0 & 0.278 & 0 & 13.348 & 13.252 \\
\hline
\end{tabular}

Note:

1: Warning Quarters include all quarters when warnings are issued by warning firms. Because a warning-firm may have issued multiple warnings during a fiscal year, that is why the number of quarterly warnings is greater than the number of warning firms in Panel A.

2: Non-warning Quarters are quarters that experice a negative earnings surprise before the confession window but did not warn by non-warning firms. Because a non-warning firm could have multiple non-warning quarters during a fiscal year, that is why the number of quarterly non-warnings is greater than the number of non-warning firms in Panel A.

${ }^{3} \Delta$ : After-warnings (After-confession-window) value minus before-warnings (before-confession-window) value for warnings and non-warnings respectively;

Variable Definitions:

Predicted RISK = Predicted value of litigation risk. See Appendix B for computation details;

$\mathrm{AFE}=\mathrm{AFE}$ before warnings and before confession window is actual EPS minus the most recent consensus analyst forecast measured at one day before the confession window; SUR after warnings and after confession window is actual EPS minus the most consensus analysts forecast measured at the earnings annoucement

$\mathrm{ABS}(\mathrm{AFE})=$ Absolute value of $\mathrm{AFE}$;

MEET $=1$ if $\mathrm{AFE}<=0$ and zero otherwise. 
Table 10: Analysis of the Reduced Turnover for Warning Firms

$$
\begin{aligned}
& \operatorname{Pr}\left(\mathrm{TURN}_{\mathrm{it}+1}\right)=\Phi\left(\beta_{0}+\beta_{1} \mathrm{WARN}_{\mathrm{it}}+\beta_{2} \Delta \mathrm{ROA}_{-} \mathrm{ADJ}\right. \\
&+\beta_{5} \mathrm{AGE}_{\mathrm{it}+1}+\beta_{6} \mathrm{BOSS}_{3} \mathrm{RET}_{\mathrm{it}}+\beta_{7} \mathrm{FE}_{-} \mathrm{ADJ}_{\mathrm{it}}+\beta_{8} \operatorname{RETVAR}_{\mathrm{it}}+\beta_{9} \mathrm{TENE}_{\mathrm{TER}} \mathrm{TE}_{\mathrm{it}+1} \\
&+\beta_{10} \mathrm{HHI}+\beta_{11} \mathrm{ROAVAR}_{\mathrm{it}} \\
&\left.\beta_{12} \mathrm{IMR} \times \mathrm{WARN}_{\mathrm{it}}+\beta_{13} \mathrm{IMR} \times\left(1-\mathrm{WARN}_{\mathrm{it}}\right)+\varepsilon_{\mathrm{it}}\right)
\end{aligned}
$$

\begin{tabular}{|c|c|c|c|c|c|c|c|c|c|}
\hline \multirow[b]{2}{*}{ Independent Variables ${ }^{1}$} & \multirow{2}{*}{$\begin{array}{c}\text { Predicted } \\
\text { Sign }\end{array}$} & \multicolumn{4}{|c|}{ no control for self-selection } & \multicolumn{4}{|c|}{ control for self-selection } \\
\hline & & Coef. & $\begin{array}{c}\text { Robust } \\
\text { Std. Err }{ }^{2}\end{array}$ & $\mathrm{P}$-value ${ }^{3}$ & $\begin{array}{l}\text { Marginal } \\
\text { Effect }\end{array}$ & Coef. & $\begin{array}{l}\text { Robust } \\
\text { Std. Err }{ }^{2}\end{array}$ & P-value ${ }^{3}$ & $\begin{array}{c}\text { Marginal } \\
\text { Effect }\end{array}$ \\
\hline Intercept & & -0.946 & 0.254 & 0.000 & & -0.905 & 0.258 & 0.000 & \\
\hline WARN & - & 0.149 & 0.065 & 0.011 & 0.029 & -0.372 & 0.266 & 0.081 & -0.059 \\
\hline$\triangle \mathrm{ROA}$ ADJ & - & -0.031 & 0.235 & 0.447 & -0.006 & -0.091 & 0.240 & 0.352 & -0.017 \\
\hline RET_ADJ & - & -0.157 & 0.073 & 0.015 & -0.029 & -0.162 & 0.073 & 0.014 & -0.030 \\
\hline AGE_63 & + & 0.374 & 0.094 & 0.000 & 0.083 & 0.385 & 0.094 & 0.000 & 0.086 \\
\hline AGE & + & -0.005 & 0.004 & 0.110 & -0.001 & -0.006 & 0.004 & 0.094 & -0.001 \\
\hline LOSS & + & 0.130 & 0.072 & 0.036 & 0.025 & 0.139 & 0.072 & 0.028 & 0.027 \\
\hline FE_ADJ & - & -1.212 & 0.567 & 0.016 & -0.223 & -1.346 & 0.571 & 0.009 & -0.247 \\
\hline RETVAR & + & 0.173 & 1.017 & 0.433 & 0.032 & 0.246 & 1.013 & 0.405 & 0.045 \\
\hline TENURE & + & 0.072 & 0.036 & 0.021 & 0.013 & 0.074 & 0.036 & 0.019 & 0.014 \\
\hline HHI & - & -1.058 & 0.477 & 0.013 & -0.195 & -1.069 & 0.475 & 0.013 & -0.196 \\
\hline ROAVAR & - & -0.391 & 0.329 & 0.118 & -0.072 & -0.450 & 0.328 & 0.085 & -0.083 \\
\hline IMR*WARN & & & & & & 0.354 & 0.182 & 0.051 & 0.065 \\
\hline IMR $*(1-W A R N)$ & & & & & & 0.142 & 0.204 & 0.486 & 0.026 \\
\hline Year dummy & & & ye & es & & & & es & \\
\hline Pseudo R² & & & 0.0 & 59 & & & 0. & 60 & \\
\hline Number of obs & & & 4,3 & 369 & & & & 69 & \\
\hline
\end{tabular}

${ }^{1}$ Variable definitions:

All variables are as defined in Table 4.

2:The standard errors are adjusted for heteroscedasticity.

${ }^{3}: \mathrm{P}$-values are based on one-tailed for variables with predicted signs and two-tailed for variables without predicted signs. 
